DNA Libraryof Life, research article

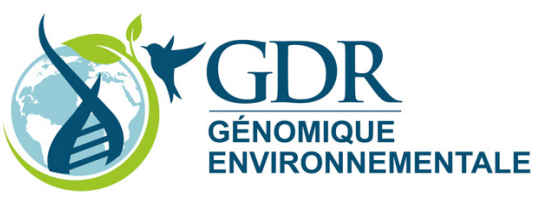

\title{
Phylogenetic analysis and systematics of the Acrapex unicolora Hampson species complex (Lepidoptera, Noctuidae, Noctuinae, Apameini), with the description of five new species from the Afrotropics
}

\author{
Bruno LE RU ${ }^{1, *}$, Claire CAPDEVIELLE-DULAC ${ }^{2}$, Boaz K. MUSYOKA ${ }^{3}$, \\ Beatrice PALLANGYO ${ }^{4}$, Mohamedi NJAKU ${ }^{5}$, Onésime MUBENGA ${ }^{6}$, \\ Gilson CHIPABIKA ${ }^{7}$, Rose NDEMAH $^{8}$, Grégoire BANI ${ }^{9}$, \\ Richard MOLO ${ }^{10}$, George ONG'AMO ${ }^{11}$ \& Gael J. KERGOAT ${ }^{12}$
}

1,2 IRD/CNRS, UMR IRD 247 EGCE, Laboratoire Evolution Génomes Spéciation, Avenue de la terrasse, BP 1, 91198 Gif-sur-Yvette, France and Université Paris-Sud 11, 91405 Orsay, France.

${ }_{1,3}^{13}$ Unité de Recherche UMR 247, African Insect Science for Food and

Health (icipe), PO Box 30772-00100, Nairobi, Kenya.

${ }^{4,5}$ Biocontrol Program, PO Box 30031, Kibaha, Tanzania.

${ }^{6}$ Faculté des Sciences agronomiques, Université de Kisangani,

Kisangani, Democratic Republic of the Congo.

${ }^{7}$ Zambia Agriculture Research Institute, Mount Maluku

Central Research Station, PO Box 8, Chilanga, Zambia.

${ }^{8}$ International Institute of Tropical Agriculture, PO Box 2008, Messa, Yaoundé, Cameroon.

${ }^{9}$ Centre de Recherches Agronomiques de Loudima (CRAL), BP 28, Loudima, Republic of the Congo.

${ }^{10}$ Namulonge Agricultural and Animal Production Research

Institute (NAARI), PO Box 7084, Kampala, Uganda.

${ }^{11}$ School of Biological Science, College of Physical and Biological Sciences (Chiromo Campus),

University of Nairobi, PO Box 30197, Nairobi, Kenya.

${ }^{12}$ INRA - UMR 1062 CBGP (INRA, IRD, Cirad, Montpellier SupAgro),

755 Avenue du campus Agropolis, 34988 Montferrier-sur-Lez, France.

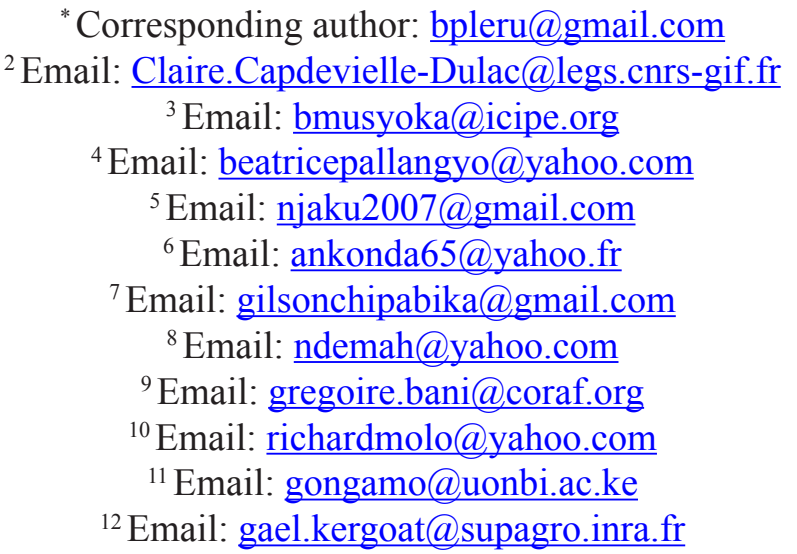


${ }^{1}$ urn:Isid:zoobank.org:author:BF55B36D-2273-4AA7-92BE-C8DA20DBF678

${ }^{2}$ urn:lsid:zoobank.org:author:9C40F53E-5BC6-406A-8230-6B8E00F5B2AE

${ }^{3}$ urn:lsid:zoobank.org:author:F177CAA9-1AD5-44AE-88AF-58DF56586BB6

${ }^{4}$ urn:Isid:zoobank.org:author:DDD832AF-84D5-48C5-9249-D19949B3840E

${ }^{5}$ urn:lsid:zoobank.org:author:93D51B7B-CF48-4CE8-BA13-41EFF642B665

${ }^{6}$ urn:Isid:zoobank.org:author:05FA0646-92A6-4FE3-9CF7-1A06C52B5F0B

${ }^{7}$ urn:Isid:zoobank.org:author:D01FA644-EF0B-4852-B33F-026222AD282C

${ }^{8}$ urn:Isid:zoobank.org:author:DFFA9646-C7A1-42C5-8135-190948EECB29

${ }^{9}$ urn:1sid:zoobank.org:author:3D4EC480-0F6C-4ADB-A3CE-D977B6C6198A

${ }^{10}$ urn:Isid:zoobank.org:author:ED929AC0-5942-4A7E-983F-4C10700F3012

${ }^{11}$ urn:Isid:zoobank.org:author:0AAB27E8-93D1-4ABD-98E6-F6E9E7C7CC0B

${ }^{12}$ urn:lsid:zoobank.org:author:D763F7EC-A1C9-45FF-88FB-408E3953F9A8

\begin{abstract}
Ten morphologically similar species of Acrapex Hampson, 1891 (Lepidoptera, Noctuidae, Noctuinae, Apameini) from Central and Eastern Africa are reviewed, including five new species: Acrapex kafula le Ru sp. nov., A. kavumba le Ru sp. nov., A. kiakouama le Ru sp. nov., A. miscantha le Ru sp. nov. and A. simillima le Ru sp. nov. Evidence is provided to transfer the monotypic genus Poecopa Bowden, 1956 to the genus Acrapex. Host plants of five species are recorded, some of them for the first time. Acrapex kavumba sp. nov., A. miscantha sp. nov. and A. simillima sp. nov. were found on one host plant each. Acrapex mediopuncta, previously reported in West Africa from Pennisetum purpureum Schumach., Rottboellia compressa L., Setaria megaphylla (Steud) Dur. \& Schinz. and Sorghum arundinaceum (Desv.) Stapf, was only found from S. megaphylla in Central Africa. Larvae of Acrapex unicolora were collected on Andropogon gayanus Kunth, Chrysopogon zizanoides (L.) Roberty, Cymbopogon schoenanthus subsp. proximus (Hochst. ex A.Rich.) Maire \& Weller, Cymbopogon pospischiilii (K.Schum.) C.E.Hubb., Hyparrhenia diplandra (Hack.) Stapf and Setaria sphacelata (Schumach.) Moss. We also conducted molecular phylogenetic analyses (using maximum likelihood) and molecular species delimitation analyses on a comprehensive sample of 61 specimens belonging to eight of the studied species. Molecular phylogenetic analyses provided additional evidence of the synonymy of Acrapex and Poecopa, whereas molecular species delimitation analyses support the validity of the five newly described species and unravel another potential new species, only collected in the larval stage.
\end{abstract}

Keywords. Acrapex, Afrotropical Region, Apameini, Noctuidae, Sesamiina.

Le Ru B., Capdevielle-Dulac C., Musyoka B.K., Pallangyo B., Njaku M., Mubenga O., Chipabika G., Ndemah R., Bani G., Molo R. Ong'amo G. \& Kergoat G.J. 2017. Phylogenetic analysis and systematics of the Acrapex unicolora Hampson species complex (Lepidoptera, Noctuidae, Noctuinae, Apameini), with the description of five new species from the Afrotropics. European Journal of Taxonomy 270: 1-36. http://dx.doi.org/10.5852/ ejt.2017.270

\title{
Introduction
}

Among the African noctuid stem borers of the subtribe Sesamiina (Lepidoptera, Noctuidae, Noctuinae, Apameini) the genus Acrapex Hampson, 1891 consists of about 90 species that are mostly distributed in the Afrotropical region (Le Ru et al. 2014). Until recently, very little was known about Acrapex host preferences as specimens had been obtained mainly from light trap collections. Extensive surveys conducted since 2004 (Le Ru et al. 2006 a, 2006b; Ong'amo et al. 2006, 2013, 2014; Ndemah et al. 2007; Matama-Kauma et al. 2008; Moolman et al. 2014) in several sub-Saharan countries, targeting wild habitats rich in Poaceae and combining infested host plant collections and light traps, allowed us to obtain several hundred specimens of Acrapex. A recent study by Le Ru et al. (2014) focused on a 
small group of morphologically related species belonging to subsets of two (groups B and C) of the four morphological groups that have been defined by Berio (1973) based on male genitalia. The latter study unravelled no less than six new species, thus suggesting that the species diversity of Acrapex in SubSaharan Africa is greatly underestimated (Le Ru et al. 2014).

In the present study, we focus on a species complex that consists of A. unicolora Hampson, 1910 and nine morphologically related species (five of which are new to science). These species constitute another subset of group B as defined by Berio (1973); the other subset corresponds to the A. stygiata (Hampson, 1910) group (Le Ru et al. 2014). Our subset of interest (hereafter referred to as the A. unicolora group) consists of A. cuprescens (Hampson, 1910), A. malagasy Viette, 1967, A parvaclara Berio, 1973, A. unicolora, A. mediopuncta (Bowden, 1956) comb. nov., A. kafula le Ru sp. nov., A. kavumba le Ru sp. nov., A. kiakouama le Ru sp. nov., A. miscantha le Ru sp. nov. and A. simillima le Ru sp. nov. It is characterised by the following combination of characters: (i) valve short and broad at basal half, cucullus rounded and tufted, with medium size hairs; (ii) coastal margin slightly broadened on the inner side and produced into a tooth-shaped spine, pointed and slightly curved inwardly; (iii) juxta large, plate-like, widening to the top without sclerotisation; (iv) aedeagus short, stout, slightly curved, with two lateral areas adorned with short setae; (v) vesica hand-shaped, with a tuft of cornutus, needle-shaped.

For this study we include the description of the five new species which have been cross-checked against all Acrapex types preserved in museums to avoid the coinage of synonymies. We also provide a supplemental description for five species of the A. unicolora group, with female genitalia presented for the first time for A. cuprescens, A. parvaclara and A. unicolora. Finally, we conduct phylogenetic analyses on a multi-marker molecular dataset (four mitochondrial gene fragments and two nuclear gene fragments) to explore species boundaries and investigate the phylogenetic placement of several species.

\section{Material and methods}

\section{Sampling}

Sampling of visually damaged grasses (Poales) in Eastern and Southeastern Africa was conducted over ten years (2004-2014) to collect the larval stages of noctuid stem borers within their wild host plants (Le Ru et al. 2006a, 2006b). Larvae were reared on an artificial diet (Onyango \& Ochieng'Odero 1994) until pupation and the emergence of adults (Le Ru et al. 2006a, 2006b). A total of 271 larvae belonging to the group of interest were sampled in the localities listed in Table 1. In addition, 185 adults from this species group were collected in light traps set up in Cameroon, Kenya, the Republic of the Congo, Tanzania, Uganda and Zambia. The morphological study is based on 72 adult specimens belonging to 10 Acrapex species collected in 46 localities in seven countries: Cameroon, the Democratic Republic of the Congo, Kenya, the Republic of the Congo, Tanzania, Uganda and Zambia (see also Le Ru et al. 2014). Plant specimens were identified by Simon Mathenge (Botany Department, University of Nairobi, Kenya).

\section{Morphological study}

Genitalia were dissected after immersion of the end of the abdomen in a boiling $10 \%$ potash bath for a few minutes, then cleaned, immersed in absolute alcohol for a few minutes and mounted on slides in Euparal (after separating the aedeagus from the rest of the genitalia in the male).

Collected insects were identified by comparison with types and specimens housed in the following institutions:

BMNH $=$ Natural History Museum, London, UK

MCSN = Museo Civico di Storia Naturale di Milano, Milan, Italy 
Table 1. Localities at which specimens of the Acrapex unicolora group were collected. [continued on next page]

\begin{tabular}{|c|c|c|c|c|c|}
\hline Country & Locality & Latitude & Longitude & $\begin{array}{l}\text { Altitude } \\
\text { (mII.a.s.t.) }\end{array}$ & Acrapex species \\
\hline Angola & Ndalatando & $09^{\circ} 18^{\prime} 14^{\prime \prime} \mathrm{S}$ & $14^{\circ} 55^{\prime} 03^{\prime \prime} \mathrm{E}$ & 827 & A. unicolora \\
\hline \multirow[t]{5}{*}{ Cameroon } & Babessi & $06^{\circ} 01^{\prime} 56^{\prime \prime} \mathrm{N}$ & $10^{\circ} 33^{\prime} 07^{\prime \prime} \mathrm{E}$ & 1203 & A. parvaclara \\
\hline & Ndop & $05^{\circ} 58^{\prime} 40^{\prime \prime} \mathrm{N}$ & $10^{\circ} 24^{\prime} 25^{\prime \prime} \mathrm{E}$ & 1182 & A. parvaclara \\
\hline & Sanaga River & $04^{\circ} 22^{\prime} 23^{\prime \prime} \mathrm{N}$ & $11^{\circ} 15^{\prime} 10^{\prime \prime} \mathrm{E}$ & 388 & A. kafula sp. nov. \\
\hline & Tapare & $06^{\circ} 02^{\prime} 16^{\prime \prime} \mathrm{N}$ & $14^{\circ} 23^{\prime} 59^{\prime \prime} \mathrm{E}$ & 870 & A. mediopuncta \\
\hline & Wete-Wete & $04^{\circ} 04^{\prime} 25^{\prime \prime} \mathrm{N}$ & $09^{\circ} 01^{\prime} 15^{\prime \prime} \mathrm{E}$ & 30 & A. mediopuncta \\
\hline $\begin{array}{l}\text { Democratic Republic } \\
\text { of the Congo }\end{array}$ & Yayoli & $00^{\circ} 49^{\prime} 34^{\prime \prime} \mathrm{N}$ & $24^{\circ} 18^{\prime} 45^{\prime \prime} \mathrm{E}$ & 374 & A. mediopuncta \\
\hline \multirow[t]{4}{*}{ Kenya } & Kakamega Forest & $00^{\circ} 22^{\prime} 32^{\prime \prime} \mathrm{N}$ & $34^{\circ} 53^{\prime} 40^{\prime \prime} \mathrm{E}$ & 1430 & A. simillima sp. nov. \\
\hline & Ruiru-Aukland & $01^{\circ} 05^{\prime} 04^{\prime \prime} \mathrm{S}$ & $36^{\circ} 55^{\prime} 37^{\prime \prime} \mathrm{E}$ & 1595 & A. kafula sp. nov. \\
\hline & Ruma Main Gate & $00^{\circ} 38^{\prime} 17^{\prime \prime} \mathrm{S}$ & $34^{\circ} 20^{\prime} 13^{\prime \prime} \mathrm{E}$ & 1254 & A. kafula sp. nov. \\
\hline & Ruma Sindo & $00^{\circ} 36^{\prime} 18^{\prime \prime} \mathrm{S}$ & $34^{\circ} 16^{\prime} 03^{\prime \prime} \mathrm{E}$ & 1221 & A. kafula sp. nov. \\
\hline Malawi & Mlanje Plateau & $15^{\circ} 58^{\prime} 47^{\prime \prime} \mathrm{S}$ & $35^{\circ} 35^{\prime} 50^{\prime \prime} \mathrm{E}$ & 1850 & A. unicolora \\
\hline \multirow{7}{*}{$\begin{array}{l}\text { Republic } \\
\text { of the Congo }\end{array}$} & Bidoua & $03^{\circ} 28^{\prime} 26^{\prime \prime} \mathrm{S}$ & $13^{\circ} 24^{\prime} 48^{\prime \prime} \mathrm{E}$ & 484 & Acrapex sp. \\
\hline & Forêt de Loudima & $04^{\circ} 04^{\prime} 38^{\prime \prime} \mathrm{S}$ & $12^{\circ} 57^{\prime} 59^{\prime \prime} \mathrm{E}$ & 142 & A. unicolora \\
\hline & Kalakundu & $04^{\circ} 22^{\prime} 09^{\prime \prime} \mathrm{S}$ & $13^{\circ} 40^{\prime} 31^{\prime \prime} \mathrm{E}$ & 325 & A. unicolora \\
\hline & Lac Loubi & $04^{\circ} 53^{\prime} 40^{\prime \prime} \mathrm{S}$ & $11^{\circ} 55^{\prime} 32^{\prime \prime} \mathrm{E}$ & 4 & A. kiakouama sp. nov. \\
\hline & Lac Nanga & $04^{\circ} 53^{\prime} 48^{\prime \prime} \mathrm{S}$ & $11^{\circ} 56^{\prime} 37^{\prime \prime} \mathrm{E}$ & 2 & A. kiakouama sp. nov., A. unicolora \\
\hline & Maloukou Trechot & $03^{\circ} 59^{\prime} 58^{\prime \prime} \mathrm{S}$ & $15^{\circ} 35^{\prime} 15^{\prime \prime} \mathrm{E}$ & 585 & A. unicolora \\
\hline & Rivière de la Léfini & $02^{\circ} 54^{\prime} 30^{\prime \prime} \mathrm{S}$ & $15^{\circ} 37^{\prime} 47^{\prime \prime} \mathrm{E}$ & 320 & A. kafula sp. nov. \\
\hline \multirow[t]{16}{*}{ Tanzania } & Akafilo & $09^{\circ} 23^{\prime} 53^{\prime \prime} \mathrm{S}$ & $34^{\circ} 49^{\prime} 17^{\prime \prime} \mathrm{E}$ & 1922 & A. unicolora \\
\hline & Iboya & $09^{\circ} 25^{\prime} 32^{\prime \prime} \mathrm{S}$ & $35^{\circ} 03^{\prime} 41^{\prime \prime} \mathrm{E}$ & 1664 & A. unicolora \\
\hline & Igima & $09^{\circ} 13^{\prime} 14^{\prime \prime} \mathrm{S}$ & $34^{\circ} 46^{\prime} 29^{\prime \prime} \mathrm{E}$ & 1888 & A. unicolora \\
\hline & Igominyi & $09^{\circ} 27^{\prime} 14^{\prime \prime} \mathrm{S}$ & $34^{\circ} 57^{\prime} 42^{\prime \prime} \mathrm{E}$ & 1668 & A. unicolora \\
\hline & Itambo & $09^{\circ} 12^{\prime} 51^{\prime \prime} \mathrm{S}$ & $34^{\circ} 46^{\prime} 38^{\prime \prime} \mathrm{E}$ & 1888 & A. unicolora \\
\hline & Kifanya & $09^{\circ} 33^{\prime} 27^{\prime \prime} \mathrm{S}$ & $35^{\circ} 06^{\prime} 15^{\prime \prime} \mathrm{E}$ & 1675 & A. unicolora \\
\hline & Kifanya 3 & $09^{\circ} 30^{\prime} 55^{\prime \prime} \mathrm{S}$ & $35^{\circ} 04^{\prime} 59^{\prime \prime} \mathrm{E}$ & 1685 & A. unicolora \\
\hline & Lilomwi & $09^{\circ} 36^{\prime} 12^{\prime \prime} \mathrm{S}$ & $35^{\circ} 10^{\prime} 53^{\prime \prime} \mathrm{E}$ & 1555 & A. unicolora \\
\hline & Lukumburu & $09^{\circ} 40^{\prime} 03^{\prime \prime} \mathrm{S}$ & $35^{\circ} 164^{\prime \prime} \mathrm{E}$ & 1299 & A. kafula sp. nov., A. unicolora \\
\hline & Masumbo-Ifunda & $08^{\circ} 02^{\prime} 04^{\prime \prime} \mathrm{S}$ & $35^{\circ} 28^{\prime} 45^{\prime \prime} \mathrm{E}$ & 1752 & A. unicolora \\
\hline & Mbizi Forest & $07^{\circ} 54^{\prime} 33^{\prime \prime} \mathrm{S}$ & $31^{\circ} 40^{\prime} 29^{\prime \prime} \mathrm{E}$ & 2147 & A. unicolora \\
\hline & Ngongwa & $09^{\circ} 29^{\prime} 40^{\prime \prime} \mathrm{S}$ & $35^{\circ} 03^{\prime} 08^{\prime \prime} \mathrm{E}$ & 1662 & A. unicolora \\
\hline & Sao Hill 2 & $08^{\circ} 27^{\prime} 25^{\prime \prime} \mathrm{S}$ & $35^{\circ} 10^{\prime} 02^{\prime \prime} \mathrm{E}$ & 1845 & A. kavumba sp. nov., A. unicolora \\
\hline & Tulia & $09^{\circ} 16^{\prime} 11 " \mathrm{~S}$ & $35^{\circ} 03^{\prime} 41^{\prime \prime} \mathrm{E}$ & 1734 & A. unicolora \\
\hline & Wino & $09^{\circ} 44^{\prime} 30^{\prime \prime} \mathrm{S}$ & $35^{\circ} 18^{\prime} 20^{\prime \prime} \mathrm{E}$ & 1444 & A. unicolora \\
\hline & Yakobi & $09^{\circ} 24^{\prime} 41^{\prime \prime} \mathrm{S}$ & $34^{\circ} 56^{\prime} 22^{\prime \prime} \mathrm{E}$ & 1693 & A. unicolora \\
\hline \multirow[t]{8}{*}{ Uganda } & Bwindi Forest & $01^{\circ} 01^{\prime} 05^{\prime \prime} \mathrm{S}$ & $29^{\circ} 45^{\prime} 32^{\prime \prime} \mathrm{E}$ & 2203 & A. simillima sp. nov. \\
\hline & Itojo & $00^{\circ} 50^{\prime} 33^{\prime \prime} \mathrm{N}$ & $30^{\circ} 13^{\prime} 08^{\prime \prime} \mathrm{E}$ & 1070 & A. kafula sp. nov., A. parvaclara \\
\hline & Kanga-Bukama & $00^{\circ} 12^{\prime} 54^{\prime \prime} \mathrm{S}$ & $30^{\circ} 05^{\prime} 37^{\prime \prime} \mathrm{E}$ & 1277 & A. parvaclara \\
\hline & Katonga & $00^{\circ} 01^{\prime} 35^{\prime \prime} \mathrm{S}$ & $32^{\circ} 00^{\prime} 57^{\prime \prime} \mathrm{E}$ & 1151 & A. parvaclara \\
\hline & Kayanga- Kalinzu Forest & $00^{\circ} 22^{\prime} 02^{\prime \prime} \mathrm{S}$ & $30^{\circ} 06^{\prime} 43^{\prime \prime} \mathrm{E}$ & 1447 & A. simillima sp. nov., A. parvaclara \\
\hline & Kazizi & $00^{\circ} 33^{\prime} 52^{\prime \prime} \mathrm{N}$ & $30^{\circ} 49^{\prime} 07^{\prime \prime} \mathrm{E}$ & 1251 & A. miscantha sp. nov. \\
\hline & Kibale E Forest & $00^{\circ} 38^{\prime} 45^{\prime \prime} \mathrm{N}$ & $30^{\circ} 24^{\prime} 16^{\prime \prime} \mathrm{E}$ & 1565 & A. simillima sp. nov. \\
\hline & Mihunga & $00^{\circ} 21^{\prime} 20^{\prime \prime} \mathrm{N}$ & $30^{\circ} 01^{\prime} 32^{\prime \prime} \mathrm{E}$ & 1756 & A. simillima sp. nov. \\
\hline
\end{tabular}


LE RU B. et al., Contribution to Acrapex systematics

\begin{tabular}{cccccc}
\hline Country & Locality & Latitude & Longitude & Altitude (m.a.s.l.) & Acrapex species \\
\hline Zambia & Kafulo & $14^{\circ} 08^{\prime} 44^{\prime \prime} \mathrm{S}$ & $23^{\circ} 27^{\prime} 38^{\prime \prime} \mathrm{E}$ & 1056 & A. kafula sp. nov. \\
& Kalale & $14^{\circ} 47^{\prime} 56^{\prime \prime} \mathrm{S}$ & $25^{\circ} 19^{\prime} 16^{\prime \prime} \mathrm{E}$ & 1154 & A. unicolora \\
& Kantongo & $09^{\circ} 29^{\prime} 02^{\prime \prime} \mathrm{S}$ & $32^{\circ} 37^{\prime} 54^{\prime \prime} \mathrm{E}$ & 1378 & A. unicolora \\
& Kavumba & $11^{\circ} 29^{\prime} 04^{\prime \prime} \mathrm{S}$ & $29^{\circ} 25^{\prime} 45^{\prime \prime} \mathrm{E}$ & 1193 & A. kavumba sp. nov., A. parvaclara \\
& Keundwe & $13^{\circ} 06^{\prime} 36^{\prime \prime} \mathrm{S}$ & $25^{\circ} 21^{\prime} 25^{\prime \prime} \mathrm{E}$ & 1225 & A. kavumba sp. nov., A. unicolora \\
& Khaembe Farm & $14^{\circ} 33^{\prime} 06^{\prime \prime} \mathrm{S}$ & $28^{\circ} 19^{\prime} 18^{\prime \prime} \mathrm{E}$ & 1191 & A. unicolora \\
& Ngwenya & $12^{\circ} 58^{\prime} 32^{\prime \prime} \mathrm{S}$ & $28^{\circ} 27^{\prime} 19^{\prime \prime} \mathrm{E}$ & 1243 & A. unicolora \\
& Rwanko Azhi & $12^{\circ} 13^{\prime} 13^{\prime \prime} \mathrm{S}$ & $25^{\circ} 39^{\prime} 04^{\prime \prime} \mathrm{E}$ & 1413 & A. kafula sp. nov., A. kavumba sp. nov. \\
\hline Zimbabwe & Bulawayo & $20^{\circ} 10^{\prime} 12^{\prime \prime} \mathrm{S}$ & $28^{\circ} 34^{\prime} 48^{\prime \prime} \mathrm{E}$ & 1076 & A. unicolora \\
\hline
\end{tabular}

MNHN $=$ Muséum national d'Histoire naturelle, Paris, France
MRAC $=$ Royal Museum for Central Africa, Tervuren, Belgium
NMKE $=$ National Museum of Kenya, Nairobi, Kenya
PM $=$ Pretoria Museum, Pretoria, South Africa
TMSA $=$ Ditsong National Museum of Natural History, Pretoria, South Africa

The holotypes of the new species were deposited in MNHN and paratypes were deposited in MNHN and NMKE.

\section{DNA Extraction and Sequencing}

For this study, 67 specimens of Acrapex were selected for the molecular analyses, including 60 individuals from the A. unicolora group. We also included one representative of the A. stygiata species group (A. stygiata) and five representatives of the A. albivena species group (A. albivena Hampson, 1910, A. salmona Le Ru, 2014, A. sporobola Le Ru, 2014, A. syscia Fletcher, 1961 and A. yakoba Le Ru, 2014). As outgroups, we included representatives of four other genera in the subtribe Sesamiina based on the results of several molecular studies (Toussaint et al. 2012; Le Ru et al. 2014). DNA was extracted from hind legs using Qiagen DNAeasy tissue kits (Qiagen, Hilden, Germany). Polymerase chain reaction (PCR) amplifications were conducted for four mitochondrial gene fragments: a 681 bp region of the cytochrome $c$ oxidase subunit I (COI), 1038 bp of cytochrome $b$ (Cytb), 389 bp of the ribosomal 12S RNA (12S) and 539 bp of the ribosomal 16S RNA (16S). Two nuclear gene regions were also sequenced: $835 \mathrm{bp}$ of the $28 \mathrm{~S}$ ribosomal DNA (28S) and 1230 bp of the elongation factor- $1 \alpha(\mathrm{EF} 1 \alpha)$. For both genes we used the primers and settings detailed in Kergoat et al. (2012). Resulting PCR products were processed by the French sequencing center Genoscope using a BigDye v. 3.1 sequencing kit and Applied 3730x1 sequencers. Both strands were sequenced for all specimens to minimize PCR artefacts and ambiguities. Sequences of complementary strands were automatically edited and reconciled using Geneious v. 5.1 software (available from www.geneious.com/). All the sequences generated in this study were deposited in GenBank (see Appendix for the accession numbers). Unlike the sequences of coding genes (COI, $\mathrm{Cyt} b$ and EF $1 \alpha$ ), the sequences of ribosomal genes (12S, 16S and 28S) were variable in length. Their alignment was accomplished using MAFFT v. 7 (Katoh \& Standley 2013) with default option settings. For all protein-coding genes, we used Mesquite v. 3.04 (available from www.mesquiteproject.org) to check the coding frame for possible errors or stop codons. The combination of the six gene fragments resulted in a combined dataset of 71 specimens and 4712 aligned characters. 
Table 2. Results of PartitionFinder analyses, based on the AICc.

\begin{tabular}{cc}
\hline Partitions & Models \\
\hline \#1: 12S, 16S, COI_pos3, Cytb_pos1 & GTR $+\mathrm{G}+\mathrm{I}$ \\
\#2: 28S, COI_pos1, Cytb_pos2, EF1 $\alpha \_$pos2, EF1 $\alpha \_$pos3 & GTR $+\mathrm{G}+\mathrm{I}$ \\
\#3: COI_pos2, Cyt $b \_$pos3 & GTR $+\mathrm{G}$ \\
\#4: EF1 $\_\_p o s 1$ & GTR $+\mathrm{G}$ \\
\hline
\end{tabular}

\section{Phylogenetic and molecular species delimitation analyses}

Maximum likelihood (ML) was used to infer phylogenetic relationships on the combined dataset. To improve phylogenetic accuracy we carried out partitioned analyses (Nylander et al. 2004). Partitions and substitution models were determined using PartitionFinder v. 1.1.1 (Lanfear et al. 2012), based on the corrected Akaike information criterion (AICc). Maximum Likelihood analyses were carried out with the recently developed IQ-TREE (Nguyen et al. 2015), using the web server at http://iqtree.cibiv. univie.ac.at/. IQ-TREE optimises the ML search by focusing on local optima and comparing them to find the best ML tree, and it has been shown to potentially outperform other ML programs (Nguyen et al. 2015). Based on the AICc results we used four partitions (Table 2), with the corresponding models of substitutions being determined using the Auto function on the IQ-TREE web server, following the authors' recommendations. Clade support was then assessed under IQ-TREE using ultrafast bootstrap replicates (Minh et al. 2013) (1000 replicates were used); nodes supported by bootstrap values (BV) $\geq 70 \%$ were considered strongly supported following Hillis \& Bull (1993).

For molecular species delimitation procedures, we relied on Poisson-tree-processes (PTP) analyses (Zhang et al. 2013). With the PTP model, speciation or branching events are modelled in terms of number of substitutions (represented by branch lengths). This approach has the advantage of not requiring the inference of an ultrametric tree, which is usually a time-consuming and potentially error-prone process (Astrin et al. 2012; Tang et al. 2014); it has also recently been used in several noctuid groups, providing relevant results from a morphological and ecological point of view (Le Ru et al. 2014, 2015; Dumas et al. 2015). Corresponding analyses were conducted on the web server of the Exelixis Lab (http:// species.h-its.org/ptp/), with default settings and using the best ML tree from the IQ-TREE analysis.

\section{Results}

\section{Morphological study}

After having cross-checked against museum types to avoid coincidence of synonymies, we provide morphological evidence that Acrapex Hampson, 1894 and the monotypic Poecopa Bowden, 1956 are synonyms, with Acrapex being the senior synonym. We also establish that Acrapex cuprescens (Hampson, 1910) and Acrapex rufidorsata (Hampson, 1910) comb. nov. are synonyms and that Acrapex unicolora (Hampson, 1910), Acrapex brunneosa Bethune-Baker, 1911, Busseola fuscantis Hampson, 1918, Acrapex simplex Janse, 1939, Acrapex hemiphlebia (Hampson, 1914) and Acrapex quadrata Berio, 1973 are synonyms as well. We present descriptions of five new species: A. kafula sp. nov. and A. kavumba sp. nov. from Zambia; A. kiakouama sp. nov. from the Republic of the Congo; A. miscantha sp. nov. from Uganda; A. simillima sp. nov. from Kenya and Uganda. We also provide a supplemental description of the previously described species, with male and female genitalia presented for the first time for A. parvaclara and A. unicolora. 


\section{Taxonomy}

Order Lepidoptera Linnaeus, 1758

Family Noctuidae Latreille, 1809

Subfamily Noctuinae Latreille, 1809

Tribe Apameini Boisduval, 1828

Subtribe Sesamiina Fibiger \& Goldstein, 2005

Genus Acrapex Hampson, 1891

Acrapex cuprescens (Hampson, 1910)

Figs 1A-F, 2A-I, 3A

Busseola cuprescens Hampson, 1910: 162.

Busseola rufidorsata Hampson, 1910: 163.

Acrapex cuprescens - Poole 1989: 19 (recombination, catalogue).

Busseola rufidorsata - Poole 1989: 181 (catalogue).

\section{Diagnosis}

Male easily separated from males of other species of the group by the short and stout, slightly curved aedeagus and the vesica with a tuft of needle-shaped, horizontally oriented cornutus (Fig. 2I); female easily separated from females of other species of the group by the small sclerotized area of the ductus bursae on ostial side, half the length of the ductus bursae, and with the ventral plate of the ostium bursae sclerotized, slightly bilobate and invaginated on the back side (Fig. 3A).

\section{Material examined}

\section{Holotype}

NIGERIA: $\widehat{\jmath}$, Niger Province, Minna, 9 Oct. 1910, coll. Scott Macfie, 1911-269 (BMNH, Agrotidae genitalia slide 2276).

\section{Other material}

NIGERIA: $1 \hat{\jmath}$, same locality as holotype; + , holotype of Busseola rufidorsata, Niger Province, Minna, 30 Sep. 1910, coll. Scott Macfie, 1911-269 (BMHN, Agrotidae genitalia slide 2273).

\section{Description}

The descriptions of the external features of the male holotype and of the female holotype of B. rufidorsata, by Hampson (1910) were accurate. The male looks very similar to the female; however, the general shape of the female's fore wing is more elongated at the apex (Figs 1A-B, E-F). Descriptions of the genitalia of both sexes were not provided by Hampson (1910).

WINGSPAN. $20 \mathrm{~mm}(2$ ふふ); $30 \mathrm{~mm}(1$ †).

Male Genitalia (Fig. 2A, I). Uncus long, widening in distal third, truncated at apex, tufted with long hairs on upper side. Tegumen with medium-sized rounded penniculi, vinculum pointed, with mediumsized triangular saccus, valves short and broad, cucullus rounded and tufted, with medium-sized hairs, coastal margin slightly broadened on inner side and produced into a strong, tooth-shaped spine, roundly pointed and slightly curved inwardly; juxta large, plate-like, widening to the top without sclerotisation. Aedeagus short, stout, slightly curved, with two lateral areas adorned with short setae; hand-shaped vesica with a tuft of needle-shaped, horizontally oriented cornutus. 

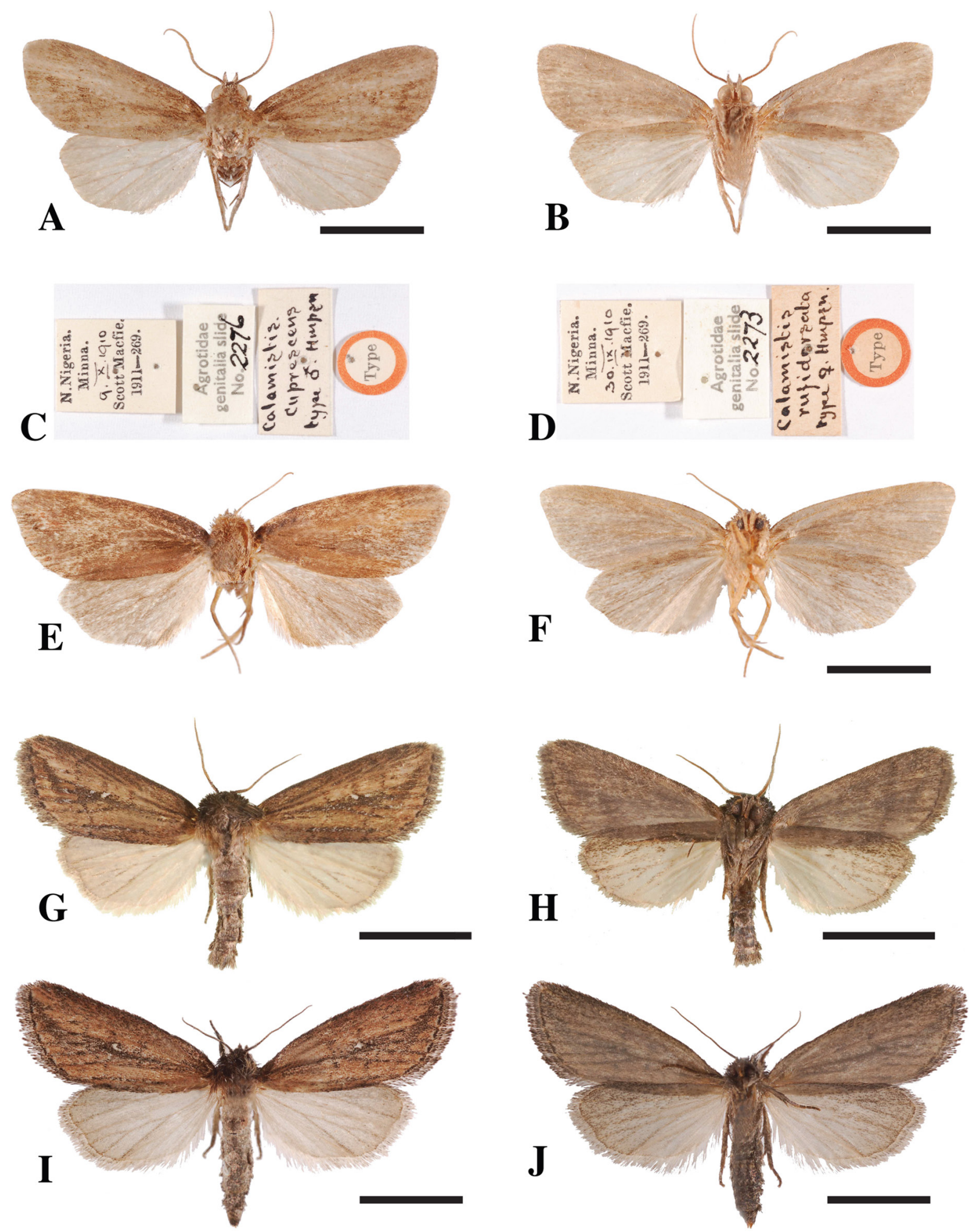

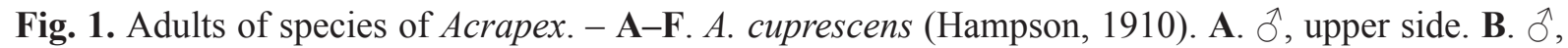
under side. C. $\hat{\partial}$, original labels from BMNH. D. ${ }_{+}$, original labels from BMNH. E. Upper side.

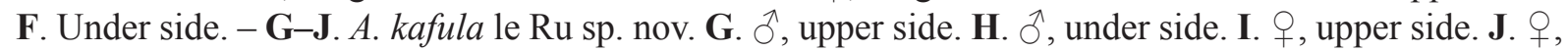
under side. Scale bars $=3 \mathrm{~mm}$. 
Female genitalia (Fig. 3A). Corpus bursae short and globular, without signum; ductus bursae short, one third as long as corpus bursae, with a small sclerotized area on ostial side, half length of ductus bursae; ductus seminalis from basal part of bursa; ventral plate of ostial bursae sclerotized, slightly bilobate and
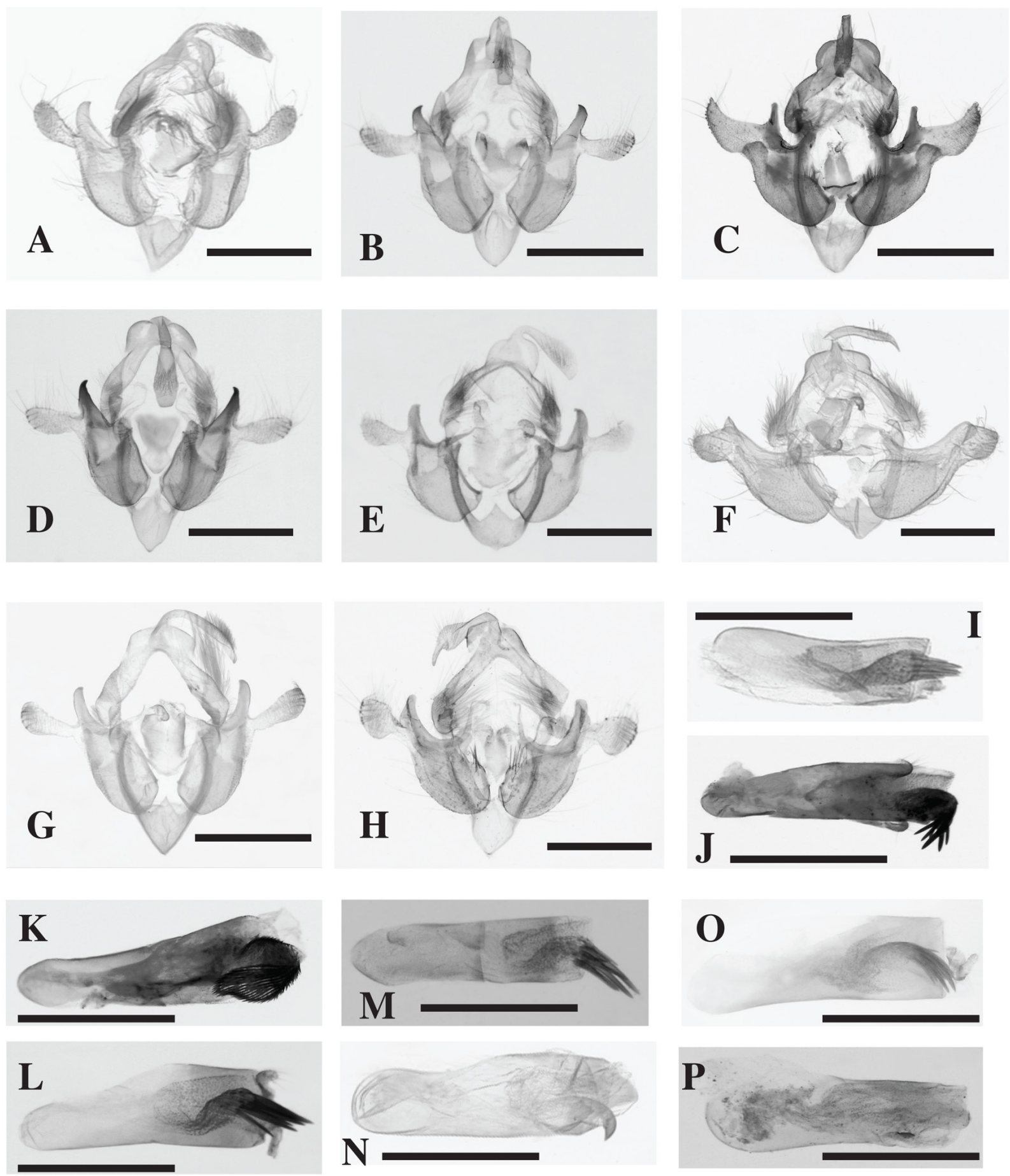

Fig. 2. Male genitalia of species of Acrapex. - A, I. A. cuprescens (Hampson, 1910). - B, J. A. kafula le $\mathrm{Ru}$ sp. nov. - C, K. A. kavumba le Ru sp. nov. - D, L. A. kiakouama le Ru sp. nov. E, M. A. malagasy Viette, 1967. - F, N. A. mediopuncta (Bowden, 1956). - G, O. A. parvaclara Berio, 1973. - H, P. A. unicolora (Hampson, 1910). Scale bars $=0.5 \mathrm{~mm}$. 
invaginated on back side, dorsal plate large, broad and weakly sclerotized. Ovipositor lobes relatively short and wide (twice as long as wide), with bluntly pointed apex, dorsal surface bearing numerous short and stout setae.

\section{Bionomics}

Biology unknown.

\section{Distribution}

Nigeria. Only known from the type locality. The record is from lowland rain forest and secondary grassland (Mosaic \#11) (White 1983) (Fig. 4), belonging to the Sudanian bioregion (Linder et al. 2012) (Fig. 5).
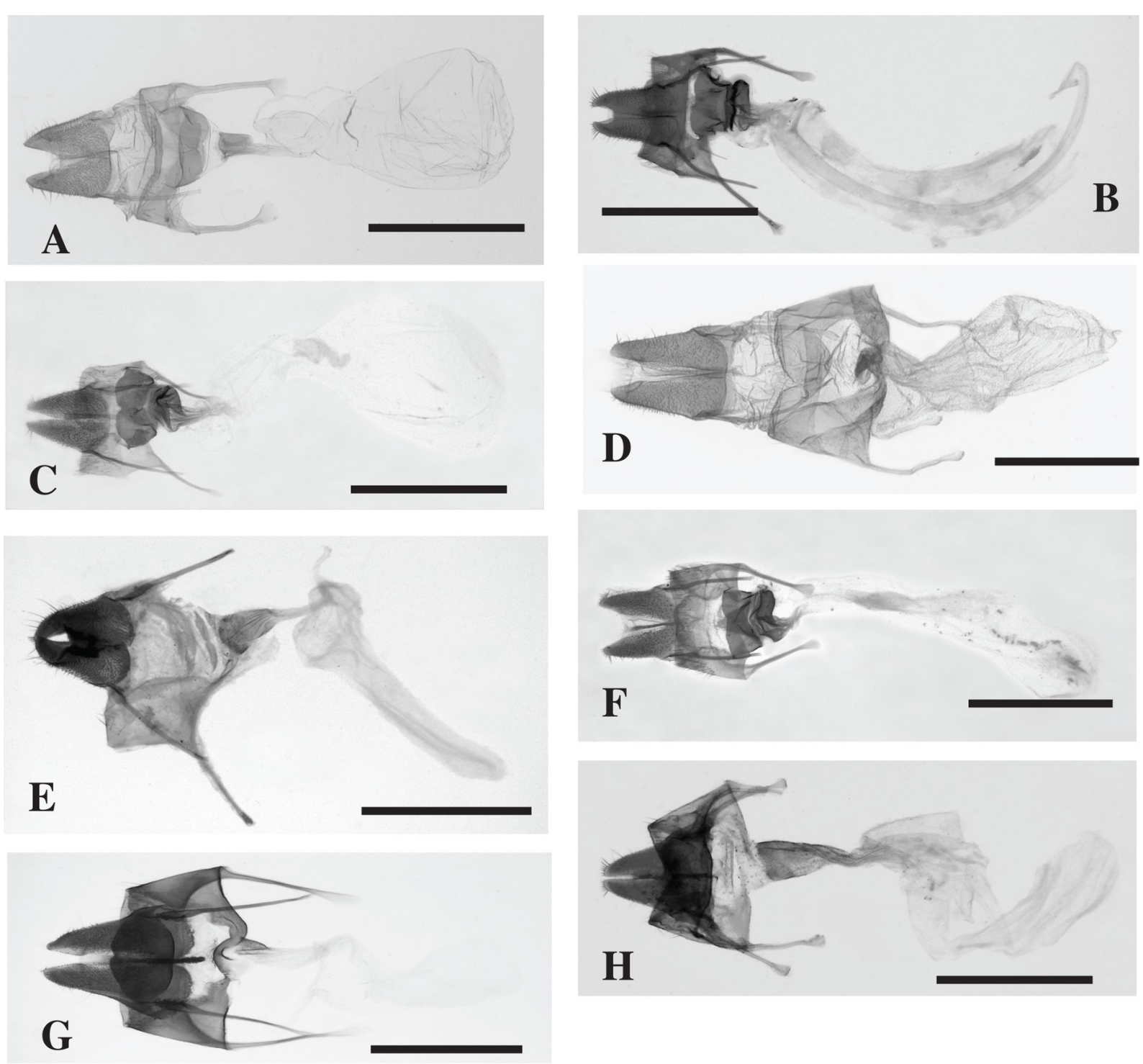

Fig. 3. Female genitalia of species of Acrapex. A. A. cuprescens (Hampson, 1910). B. A. kafula le Ru sp. nov. C. A. kiakouama le Ru sp. nov. D. A. mediopuncta (Bowden, 1956). E. A. miscantha le Ru sp. nov. F. A. parvaclara Berio, 1973. G. A. simillima le Ru sp. nov. H. A. unicolora (Hampson, 1910). Scale bars $=1 \mathrm{~mm}$. 


\section{Acrapex kafula Le Ru sp. nov. urn:lsid:zoobank.org:act:B727D00A-7E31-4B44-9B33-E6DC82D548B2}

Figs $1 \mathrm{G}-\mathrm{J}, 2 \mathrm{~B}, \mathrm{~J}, 3 \mathrm{~B}$

\section{Diagnosis}

Male easily separated from males of other species of the group by the shovel-shaped uncus (at the apex) and the distal part of the aedeagus (grooved-shaped), with the vesica having a basal tuft of needleshaped cornutus, pointed downward (Fig. 2B, J). Female easily separated from females of other species of the group by the very short ductus bursae, with a strongly sclerotised funnel-shaped connection with the ostium; antrum sclerotized, with a large, broad ventral plate, slightly bilobate, widening to the front, the anterior part shaped like a thin lip and more sclerotized than the posterior part, slightly concave (Fig. 3B).

\section{Etymology}

Named after the village of Kafulo in Zambia.

\section{Type material}

\section{Holotype}

ZAMBIA: ${ }^{\top}$, Western Province, Kafulo, 1408.726' S, 2327.638' E, 1056 m a.s.1., 20 Mar. 2012, ex light trap, B. Le Ru leg. (MNHN, gen. prep. LERU Bruno/G595).

\section{Paratypes}

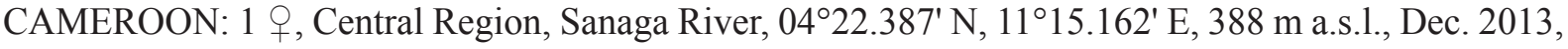
ex light trap (MNHN, gen. prep. LERU Bruno/G603).

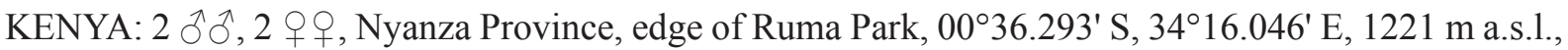
14 Nov. 2012, ex light trap, B. Le Ru leg. (MNHN, gen. prep. LERU Bruno/G511-G513-G529); 1 §, Central Province, Ruiru Aukland, 0105.063' S, 3655.621' E, 1595 m a.s.1., Jun. 2011 (MNHN).

REPUBLIC OF THE CONGO: 1 ð, Plateau Region, Lefini River, 02 ${ }^{\circ} 54.501^{\prime} \mathrm{S}, 15^{\circ} 37.7766^{\prime} \mathrm{E}, 320 \mathrm{~m}$ a.s.1., 13 Apr. 2013, ex light trap (MNHN, gen. prep. LERU Bruno/G584).

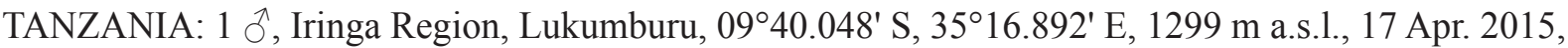
ex light trap, B. Le Ru leg. (MNHN, gen. prep. LERU Bruno/G799).

UGANDA: 2 ○ึ, Western Region, Itojo, $00^{\circ} 50.5466^{\prime} \mathrm{N}, 30^{\circ} 13.131^{\prime} \mathrm{E}, 1070 \mathrm{~m}$ a.s.1., 22 May 2014, ex light trap (MNHN, gen. prep. LERU Bruno/G714).

ZAMBIA: $1 \hat{\jmath}$, same date and locality as holotype, ex. light trap, B. Le Ru leg. (MNHN, gen. prep. LERU Bruno/G178); 1 +, same date and locality as holotype, ex light trap (MNHN, gen. prep. LERU Bruno/G165).

\section{Description}

Both sexes look similar; however, general shape of female fore wing more elongated at apex than in male and fore wings paler in females (Fig. 1G-J); antennae bright fuscous dorsally and ochreous ventrally, filiform in female and slightly ciliate in male; flagellum adorned dorsally with black scales, palpus cupreous brown, eyes fuscous. Head and base of thorax brown, thorax becoming gradually fuscous; legs brown-ringed with buff, buff on inner surface; abdomen fuscous, irrorated with buff scales. 
FORE WING. Ground colour ochreous in both sexes, suffused with fuscous scales, more heavily along veins and costal area, particularly in males; reniform indicated by a few white scales, preceded by some brown scales; longitudinal brown median fascia along lower external margin of cell, ending obliquely at apex; veins below cell adorned with white, fuscous and brown scales; postmedial row of white spots on veins; row of black elongated spots between veins on margin; fringe whitish externally, fuscous suffused with brown internally. Underside of fore wing with ground colour fuscous, densely suffused with brown scales.

HIND WING. Ground colour white, veins slightly irrorated, with fuscous scales, costa and apex more heavily suffused with fuscous scales; hind wing of males much more suffused with fuscous scales than in females; fringe white, suffused with fuscous and adorned with narrow fuscous line. Underside of hind wing white, suffused with fuscous scales but much more heavily on costa and apex; veins slightly irrorated, with fuscous scales.

WINGSPAN. 18-22 mm (6 ふぶ); 21-25 mm (5 우).

Male Genitalia (Fig. 2B, J). Uncus long, widening in distal third, shovel-shaped at apex, tufted with long hairs on upper side. Tegumen with medium-sized rounded penniculi, vinculum pointed, with mediumsized triangular saccus, valves short and broad, cucullus rounded and tufted with medium-sized hairs,
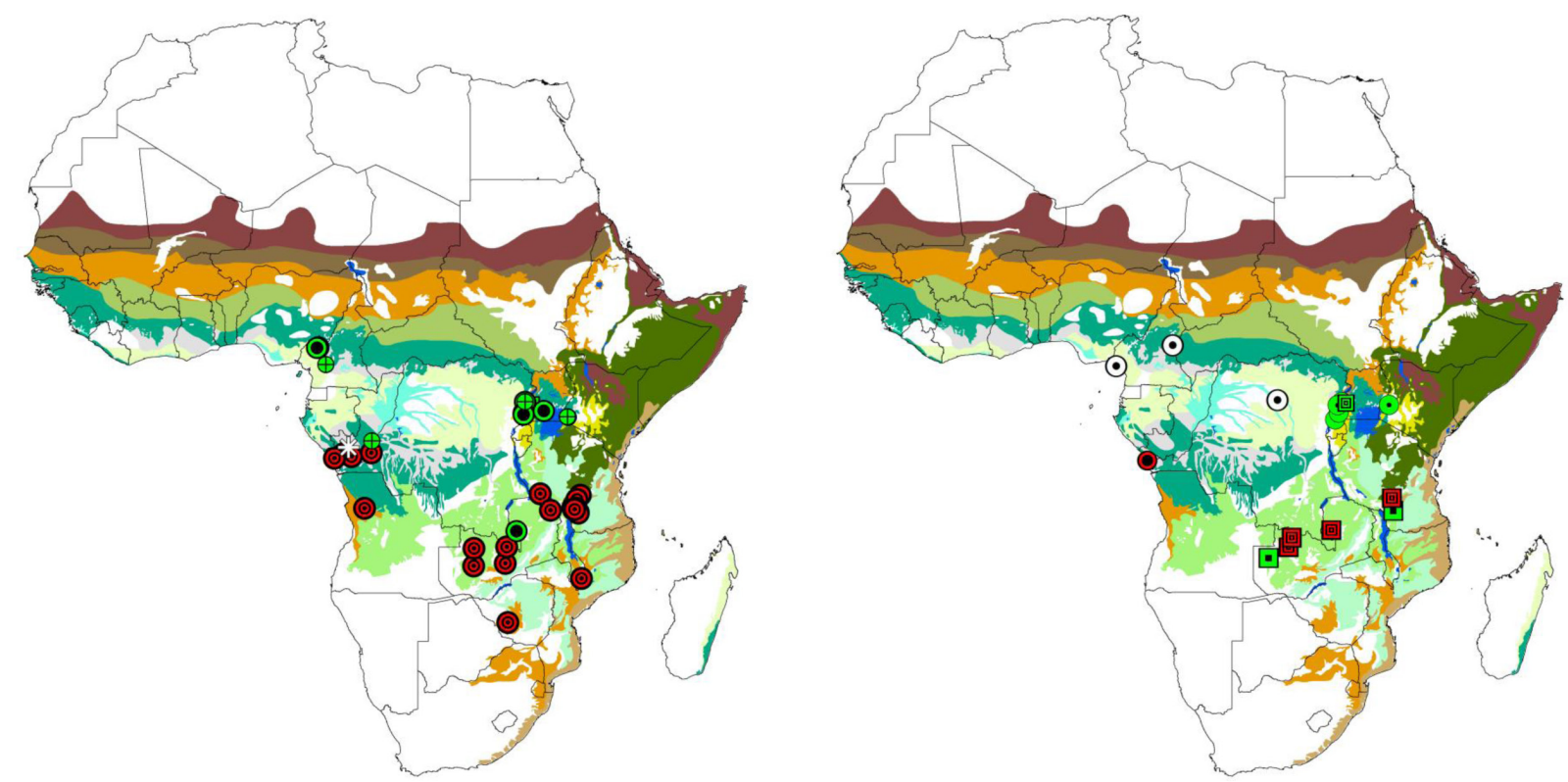

\section{Legend}

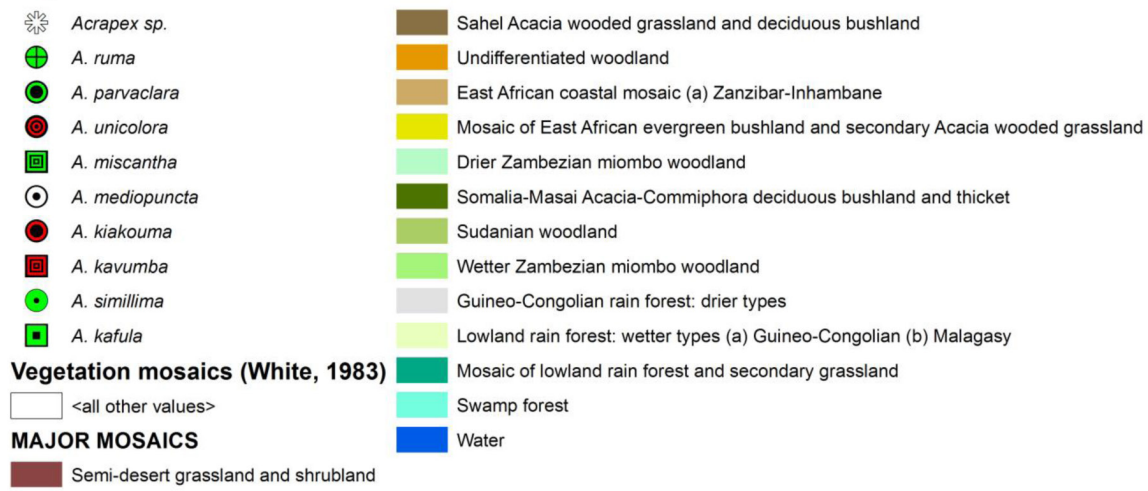

Fig. 4. Distribution map of sampled specimens of Acrapex Hampson, 1891. 
coastal margin slightly broadened on inner side and produced into strong, tooth-shaped spine, strongly sclerotized at apex, pointed and slightly curved inwardly; juxta large, plate-like, without sclerotisation. Aedeagus short, slightly curved, with two lateral areas adorned with short setae; hand-shaped vesica with basal tuft of needle-shaped cornutus, pointed downward.

Female Genitalia (Fig. 3B). Corpus bursae elongated ovoid and globular without signa; ductus bursae very short, with strongly sclerotised, funnel-shaped connection with ostium; antrum sclerotized, with large, broad ventral plate, slightly bilobate, widening to the front, anterior part shaped like a thin lip, more sclerotized than posterior part, slightly concave; dorsal plate small, weakly sclerotized. Ovipositor lobes relatively short (2.2 times as long as wide), with pointed apex, dorsal surface bearing numerous short and stout setae.

\section{Bionomics}

Biology unknown. The moths were caught in a light trap in grasslands near marshes.

\section{Distribution}

Cameroon, Kenya, the Republic of the Congo, Tanzania, Uganda and Zambia. Moths were found in a mosaic of lowland rainforest and secondary grassland (Mosaic \#11), in a mosaic of Zambezian dry evergreen forest and wetter miombo woodland (Mosaic \#21), in a mosaic of East African evergreen bushland and secondary Acacia wooded grassland (Mosaic \#45) and in undiffentiated montane vegetation (Mosaic \#19) (White 1983) (Fig. 4), belonging to the Congolian and Zambezian bioregions (Linder et al. 2012) (Fig. 5).

\section{Acrapex kavumba Le Ru sp. nov. urn:Isid:zoobank.org:act:17B55911-C7C0-4733-B131-D9C0C59FE72A}

Figs $2 \mathrm{C}, \mathrm{K}, 6 \mathrm{~A}-\mathrm{B}$

\section{Diagnosis}

Males easily separated from males of other species of the group by the spoon-shaped cucullus and the turn of the hand-shaped vesica being adorned with a large tuft of needle-shaped cornutus (Fig. 2C, K).
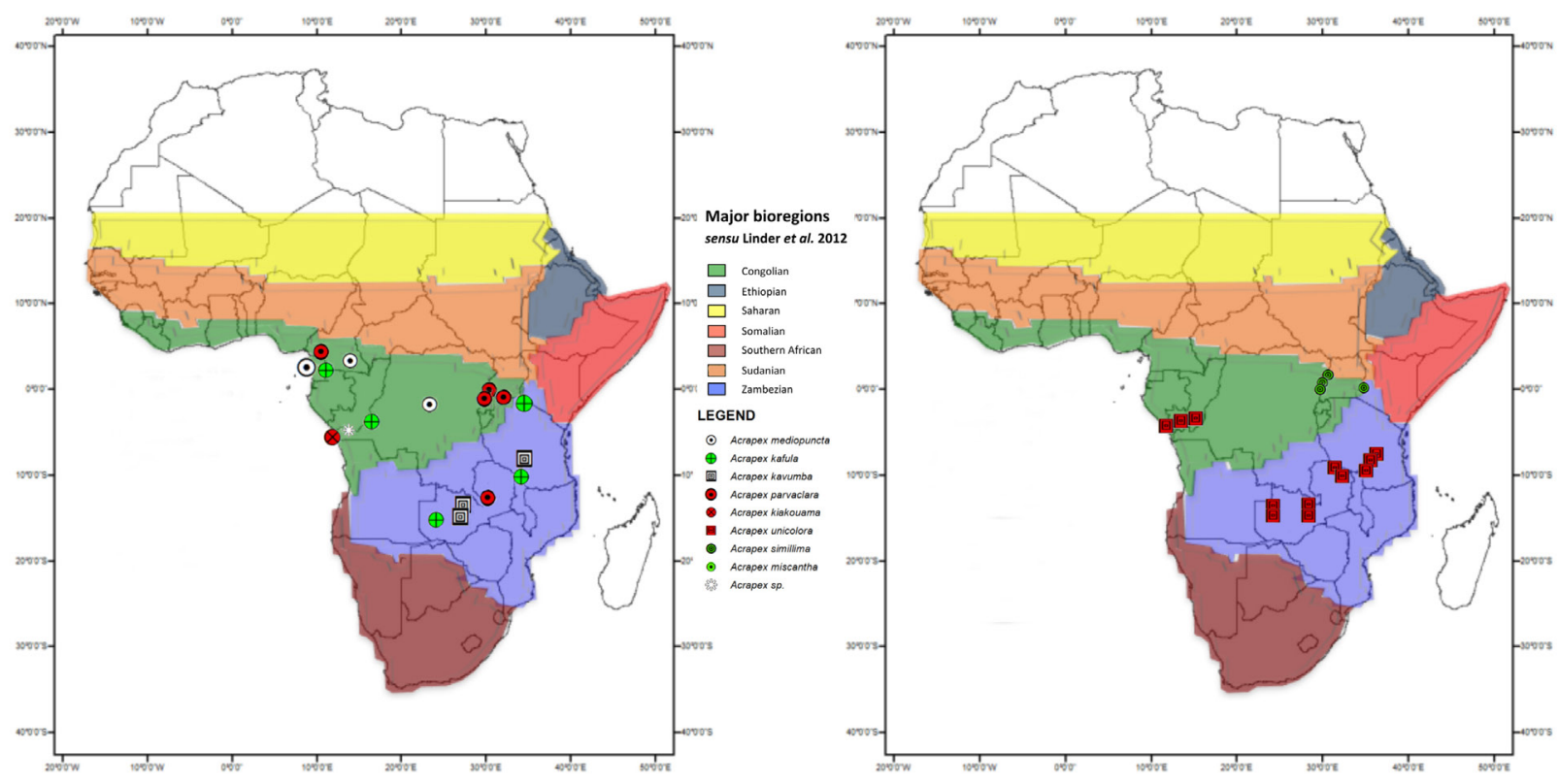

Fig. 5. Major bioregions, modified after Linder et al. (2012). 


\section{Etymology}

Named after the village of Kavumba in Zambia.

\section{Type material}

\section{Holotype}

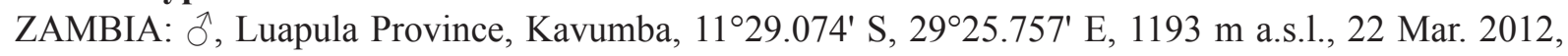
ex light trap, B. Le Ru leg. (MNHN, gen. prep. LERU Bruno/G161).

\section{Paratypes}

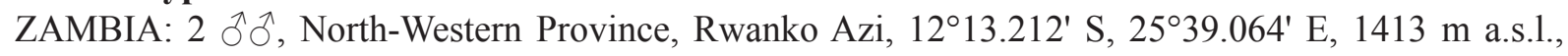
20 Mar. 2012, ex light trap (MNHN, gen. prep. LERU Bruno/G169-G377).

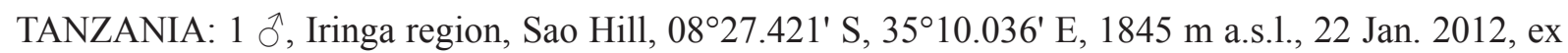

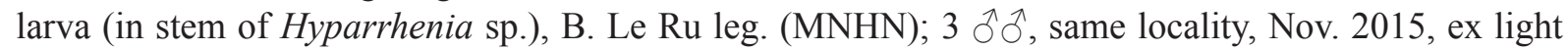
trap, B. Le Ru leg. (MNHN, gen. prep. LERU Bruno/G937).

\section{Description}

Only the male is known (Fig. 6A-B); antennae cupreous brown dorsally and ochreous ventrally, slightly ciliate; flagellum adorned dorsally with white scales, palpus cupreous brown, adorned with white scales, eyes fuscous. Head and base of thorax brown, thorax becoming gradually ochreous; legs brown-ringed with white; abdomen brown irrorated with fuscous scales, extremity of abdomen densely suffused with buff scales.

FORE WING. Ground colour dark ochreous, suffused with fuscous and brown scales, more heavily along veins and in costal area; reniform indicated by few white scales, preceded by some brown scales; longitudinal brown median fascia along lower external margin of cell, ending obliquely at apex; veins below cell adorned with white, fuscous and brown scales; postmedial row of white spots on veins; row of black elongated spots between veins on margin; fringe whitish externally, ochreous suffused with brown internally. Underside of fore wing with ground colour brown, suffused with fuscous scales on costa.

HIND wING. Uniformly brown; fringe white suffused with fuscous and adorned with narrow fuscous line. Underside of hind wing brown, suffused with fuscous scales.

WingSPAN. 21-23 mm (4 ふ઼ふ).

Male genitalia (Fig. 2C, K). Uncus long, widening in distal third, truncated at apex, tufted with long hairs on upper side. Tegumen with medium-sized rounded penniculi, vinculum pointed, with mediumsized triangular saccus, valves short and broad, cucullus spoon-shaped and tufted with medium size hairs, coastal margin slightly broadened on inner side and produced into narrow, straight, long lobe, roundly pointed; juxta oblong, pear-shaped, with long and wide neck, elongate bifid. Aedeagus short, slightly curved, with two lateral areas adorned with short setae; turn of hand-shaped vesica with large tuft of needle-shaped cornutus.

\section{Bionomics}

One larva was collected at the bottom of a stem of a Hyparrhenia sp. growing in grasslands near marshes (Table 3); like many species of Acrapex, A. kavumba sp. nov. is a markedly hygrophilous species. Unfortunately, no pictures were taken before pupation. All the moths were caught in a light trap in grasslands near marshes. 

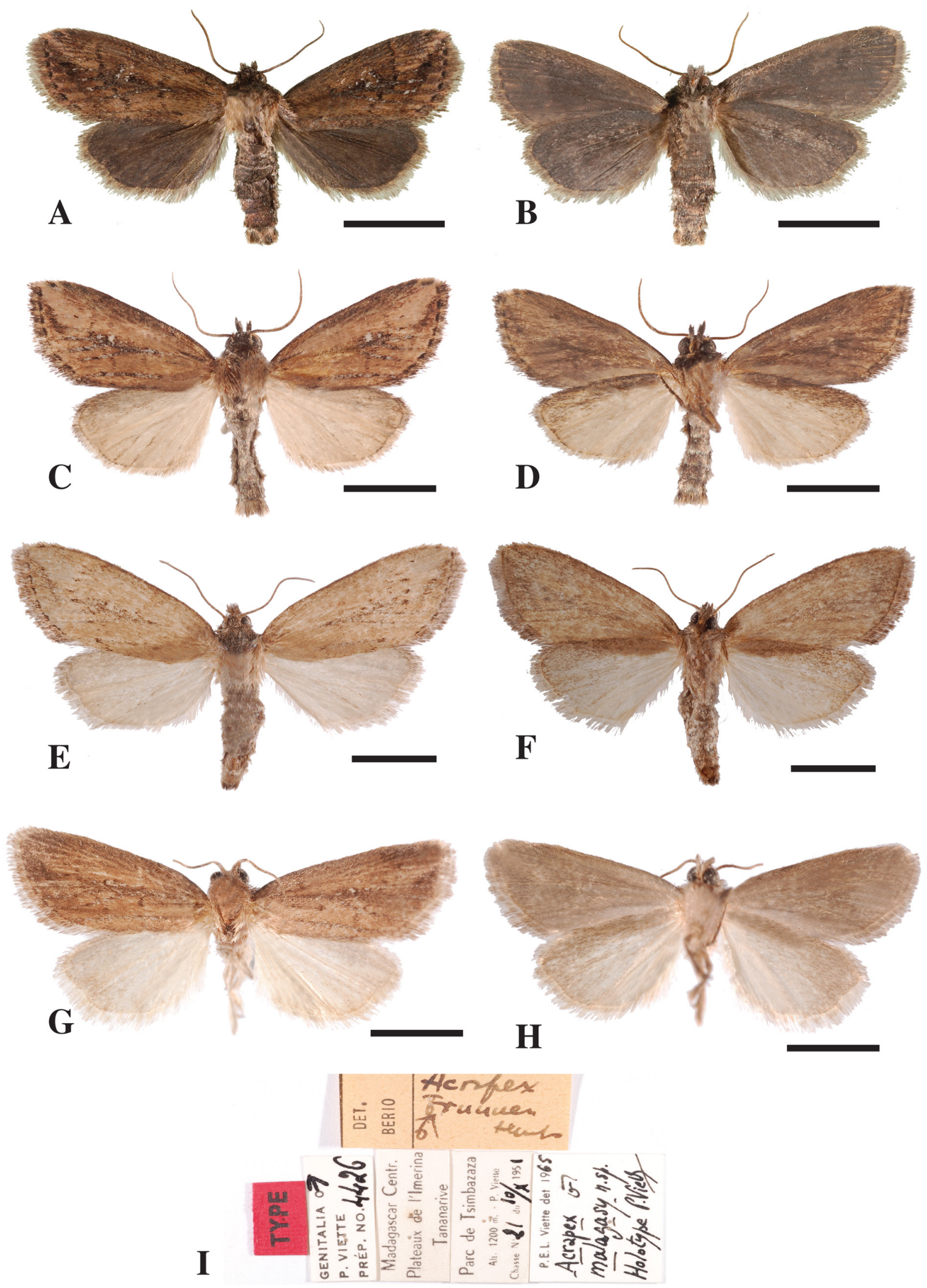

Fig. 6. Adults of species of Acrapex. - A-B. A. kavumba le Ru sp. nov. A. $\hat{\partial}$, upper side. B. $\widehat{\partial}$, under side. - C-F. A. kiakouama le Ru sp. nov. C. $\widehat{\partial}$, upper side. D. $\partial^{\lambda}$, under side. E. $q$, upper side. F. $q$,

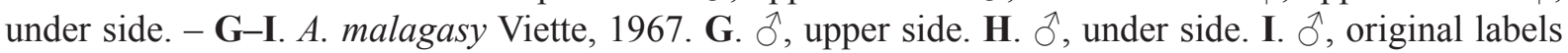
from MNHH. Scale bars $=10 \mathrm{~mm}$. 
Table 3. Host plants on which larvae of the Acrapex unicolora group were collected.

\begin{tabular}{cc}
\hline Acrapex species & Host plant species \\
\hline A. kavumba sp. nov. & Hyparrhenia sp. \\
A. mediopuncta & Pennisetum purpureum Schumach. \\
& Rottboellia compressa L. \\
& Setaria megaphylla (Steud) Dur. \& Schinz. \\
& Sorghum arundinaceum (Desv.) Stapf \\
A. miscantha sp. nov. & Miscanthus violaceus (K. Schum.) Pilg. \\
A. simillima sp. nov. & Setaria megaphylla (Steud) Dur. \& Schinz. \\
A. unicolora & Andropogon gayanus Kunth \\
& Chrysopogon zizanoides (L.) Roberty \\
& Cymbopogon giganteus Chiov. \\
& Cymbopogon nardus (L.) Rendle \\
& Hyparrhenia diplandra (Hack.) Stapf \\
Setaria sphacelata (Schumach.) Moss
\end{tabular}

\section{Distribution}

Tanzania and Zambia. The records are from a mosaic of Zambezian dry evergreen forest and wetter miombo woodland (Mosaic \#21) (White 1983) (Fig. 4), belonging to the Zambezian bioregion (Linder et al. 2012) (Fig. 5).

\section{Acrapex kiakouama Le Ru sp. nov. urn:1sid:zoobank.org:act:5FD4E344-68BA-423B-AF86-347CAD502914}

Figs 2D, L, 3C, 6C-F

\section{Diagnosis}

Male easily separated from males of other species of the group by the uncus being shovel-shaped at the apex and by the large, plate-like juxta, with a narrow pyriform base and a long and widening, slightly sclerotised neck (Fig. 2D); female easily separated from females of other species of the group by having the antrum strongly sclerotized, with a large, broad ventral plate, bilobate, widening to the front, anterior part shaped like a fleshy lip, the posterior part concave (Fig 3C).

\section{Etymology}

Named after Kiakouama, the technician who collected this species in the Republic of the Congo.

\section{Type material}

\section{Holotype}

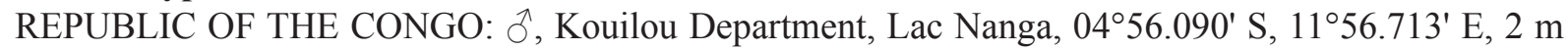
a.s.1., 17 Apr. 2013, ex light trap, B. Le Ru leg. (MNHN, gen. prep. LERU Bruno/G843).

\section{Paratypes}

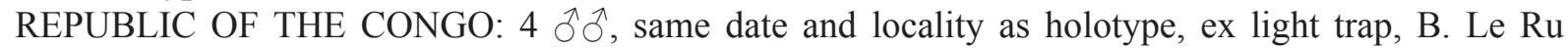
leg. (MNHN, gen. prep. LERU Bruno/G533-G537-G781); 4 + , same date and locality as holotype, ex light trap, B. Le Ru leg. (MNHN, gen. prep. LERU Bruno/G536); 1 ô, Kouilou Province, Lac Loubi, 045․ 53.57' S, $11^{\circ} 55.535^{\prime}$ E, 4 m a.s.1., 16 Apr. 2013, ex light trap, B. Le Ru leg. (MNHN). 


\section{Description}

Both sexes look similar; however, the general shape of the female fore wing is more elongated at the apex than in the male and is paler (Fig. 6C-F); antennae bright ochreous dorsally and ochreous ventrally, filiform in female and slightly ciliate in male; flagellum adorned dorsally with grey scales, palpus ochreous grey, eyes fuscous brown. Head and base of thorax bright brown, thorax ochreous; legs ochreous, ringed with grey white; abdomen grey.

FORE WING. Ground colour bright ochreous in both sexes, suffused with fuscous and brown scales, more heavily along veins and costal area, particularly in male; reniform indicated by few white scales, surrounded by some brown scales; longitudinal brown median fascia along lower external margin of cell, ending obliquely at apex; veins below cell adorned with white and fuscous scales; row of black elongated spots between veins on margin; fringe grey externally, ochreous suffused with fuscous internally. Underside of fore wing with ground colour ochreous, densely suffused with brown scales.

HIND wING. Ground colour pale ochreous in male, more whitish in female; veins slightly irrorated, with fuscous scales, costa and apex more heavily suffused with fuscous scales; hind wing of male much more suffused with fuscous scales than that of female; fringe pale ochreous, suffused with fuscous and adorned with narrow fuscous line. Underside of hind wing pale ochreous in male, more whitish in female, suffused with brown scales but much more heavily on costa and apex; veins slightly irrorated with pale fuscous scales.

WINGSPAN. 16-18 mm (4 ふふふ); 20-23 mm (7 ○ํ).

Male genitalia (Fig. 2D, K). Uncus long, widening in distal third, shovel-shaped at apex, tufted with long hairs on upper side. Tegumen with medium-sized rounded penniculi, vinculum pointed, with medium-sized triangular saccus, valves short and broad, cucullus rounded and tufted, with medium-sized hairs, coastal margin slightly broadened on the inner side and produced into strong tooth-shaped spine, strongly sclerotized at apex, pointed and curved inwardly; juxta large, plate-like, base pyriform, without sclerotization, with long and widening, slightly sclerotized neck. Aedeagus short, slightly curved, with two lateral areas adorned with short setae; hand-shaped vesica with basal tuft of needle-shaped cornutus, pointed obliquely downward.

Female genitalia (Fig. 3C). Corpus bursae long and globular, without signa; ductus bursae very short, with strongly sclerotized funnel-shaped connection with ostium; antrum strongly sclerotized, with large, broad ventral plate, bilobate, widening to the front, anterior part shaped like a fleshy lip, posterior part concave; dorsal plate small, weakly sclerotized. Ovipositor lobes relatively short (2 times as long as wide), with pointed apex, dorsal surface bearing numerous short and stout setae.

\section{Bionomics}

Biology unknown. The moths were caught in a light trap in grasslands near marshes.

\section{Distribution}

Republic of the Congo. Known from two close localities only in the Kouilou region, south coast of Pointe Noire. Moths were found in a mosaic of lowland rain forest and secondary grassland (Mosaic \#11A) (White 1983) (Fig. 4), belonging to the Congolian bioregion (Linder et al. 2012) (Fig. 5).

Acrapex malagasy Viette, 1967

Figs 2E, M, 6G-I

Acrapex malagasy Viette, 1967: 712-714, figs 552a-b, 553.

Acrapex malagasy - Poole 1989: 20 (catalogue). 


\section{Diagnosis}

Easily separated from other species of the group by the large, plate-like juxta, with the base slightly flattened, without sclerotization, with a long and widening neck, ending on each side in a rounded apex, on both sides tufted with small-sized hairs (Fig. 2E).

\section{Material examined}

\section{Holotype}

MADAGASCAR: đ̊, Plateau de l'Imerina, Tananarive, Parc de Tsimbazaza, 1200 m a.s.1., 10 Oct. 1951

(MNHN, gen. prep. 4426). Several specimens are recorded by Viette (1967).

\section{Paratype}

MADAGASCAR: $2 \widehat{ð}$, same locality and date as holotype (MNHN); $3 \widehat{\jmath}$, same locality as holotype, 8 Nov. 1954, P. Viette leg. (MNHN, gen. prep. 4438).

\section{Description}

The description of the external features of the holotype by Viette (1967) was accurate (Fig. 6G-H).

WingSPAN. 17-20 mm $(\widehat{\jmath})$ according to Viette (1967); however, only one specimen is preserved in MNHN.

Male genitalia (Fig. 2E, M). (After Viette 1967) Additional description: juxta large, plate-like, base slightly flattened, without sclerotization, with long and widening neck, ending on each side in rounded apex, on both sides tufted with small-sized hairs; aedeagus short, stout, not curved, with two lateral areas adorned with short setae; hand-shaped vesica with tuft of needle-shaped cornutus, pointed obliquely downward.

\section{Bionomics}

Biology unknown.

\section{Distribution}

Madagascar. Only known from the type locality. The record is from secondary grassland replacing upland and montane forest (Mosaic \#18) (White 1983) (Fig. 4), belonging to the Sudanian bioregion (Linder et al. 2012) (Fig. 5).

Acrapex mediopuncta (Bowden, 1956) comb. nov. Figs 2F, N, 3D, 7A-E

Poecopa mediopuncta Bowden, 1956: 418-420, figs 6-9.

Poecopa mediopuncta - Poole 1989: 818 (catalogue).

\section{Diagnosis}

Male easily separated from males of other species of the group by the broadly based, stout, strongly curved cornutus, pointed downward at a right angle (Fig. $2 \mathrm{~N}$ ); female easily separated from females of other species of the group by the small sclerotized area at the base of the ductus bursae and the weakly sclerotized antrum (Fig. 3D).

\section{Material examined}

\section{Holotype}

GHANA: गे, Gold Coast, Kwadaso, near Kumasi, 25 Jun. 1952, ex larva (in stems of Rottboellia compressa L.), J. Bowden leg. (BMNH 1953/9, Agrotidae genitalia slide 1338). 


\begin{abstract}
Allotype
GHANA: + , Gold Coast, mile 19-20 on Kumasi-Mampong Road, 31 Aug. 1951, ex larva (in stems of Setaria megaphylla (Steud) Dur. \& Schinz.), J. Bowden leg. (BMNH 1953/11, Agrotidae genitalia slide 1337).

\section{Paratype}

GHANA: $1 \hat{0}$, same locality and date as allotype; 12 paratypes of both sexes were recorded in the original description; only one was found in BMNH.

\section{Other material}

CAMEROON: $1 \partial^{\top}$, Southwest Region, Limbe, Wete Wete, $04^{\circ} 04.417^{\prime} \mathrm{N}, 09^{\circ} 01.250^{\prime} \mathrm{E}, 30 \mathrm{~m}$ a.s.1., 2 Feb. 2007, ex larva (in stem of Setaria megaphylla (Steud) Dur. \& Schinz.), B. Le Ru leg. (MNHN, gen. prep. LERU Bruno/G284).
\end{abstract}

\title{
Description
}

The descriptions of the external features of the male holotype and female allotype by Bowden (1956) were accurate. The male looks very similar to the female; however, the general colour of the fore wing is a little bit darker in the male than in the female (Fig. 7A-D).

WingSPAN. 20-32 mm (3 ふふ); 33 mm (1 ค).

Male and female genitalia (Figs 2F, N, 3D). The genitalia of both sexes were described by Bowden (1956) with sufficient detail; however, it should be added that the vesica of the aedeagus is hand-shaped with a stout, broadly based, strongly curved cornutus, pointed downward at a right angle.

\section{Bionomics}

Acrapex mediopuncta is a markedly forest species inhabiting open patches of grasses along forest roads. Larvae collected in Ghana were reported from P. purpureum, $R$. compressa, S. arundinaceum and S. megaphylla (Bowden 1956) (Table 3). The few larvae collected in Cameroon, the Democratic Republic of the Congo and the Republic of the Congo by our group were all from S. megaphylla; unfortunately, no pictures were taken before pupation. Larvae were collected at the bottom of young stems and were always solitary. Typically, plants exhibiting signs of infestation by A. mediopuncta larvae have a curled, brown, central leaf. No pupae were found in the stems, and therefore the borers probably pupate in the soil near exit holes.

\section{Distribution}

Cameroon, the Democratic Republic of the Congo, Ghana and the Republic of the Congo. The records are from Guineo-Congolian rain forests, lowland rain forests and secondary grassland vegetation mosaics (Mosaics \#1-3) (White 1983) (Fig. 4), belonging to the Congolian bioregion (Linder et al. 2012) (Fig. 5).

\section{Acrapex miscantha Le Ru sp. nov. urn:lsid:zoobank.org:act:A4657886-D162-4D14-BCD4-46C7A02CC426}

Figs $3 \mathrm{E}, 7 \mathrm{~F}-\mathrm{G}$

\section{Diagnosis}

Female easily separated from females of other species of the group by the strongly curved and toothshaped ovipositor lobes (Fig. 3E).

\section{Etymology}

Named after the host-plant Miscanthus violaceus (K.Schum.) Pilg. in Uganda. 


\section{Material examined}

\section{Holotype}

UGANDA: + , Occidental Province, Kyenjojo, Kazizi, 00³3.865' N, 3049.117' E, 1251 m a.s.l., 24 May 2014, ex larva (in stems of Miscanthus violaceus), B. Le Ru leg. (MNHN, gen. prep. LERU Bruno/G734).
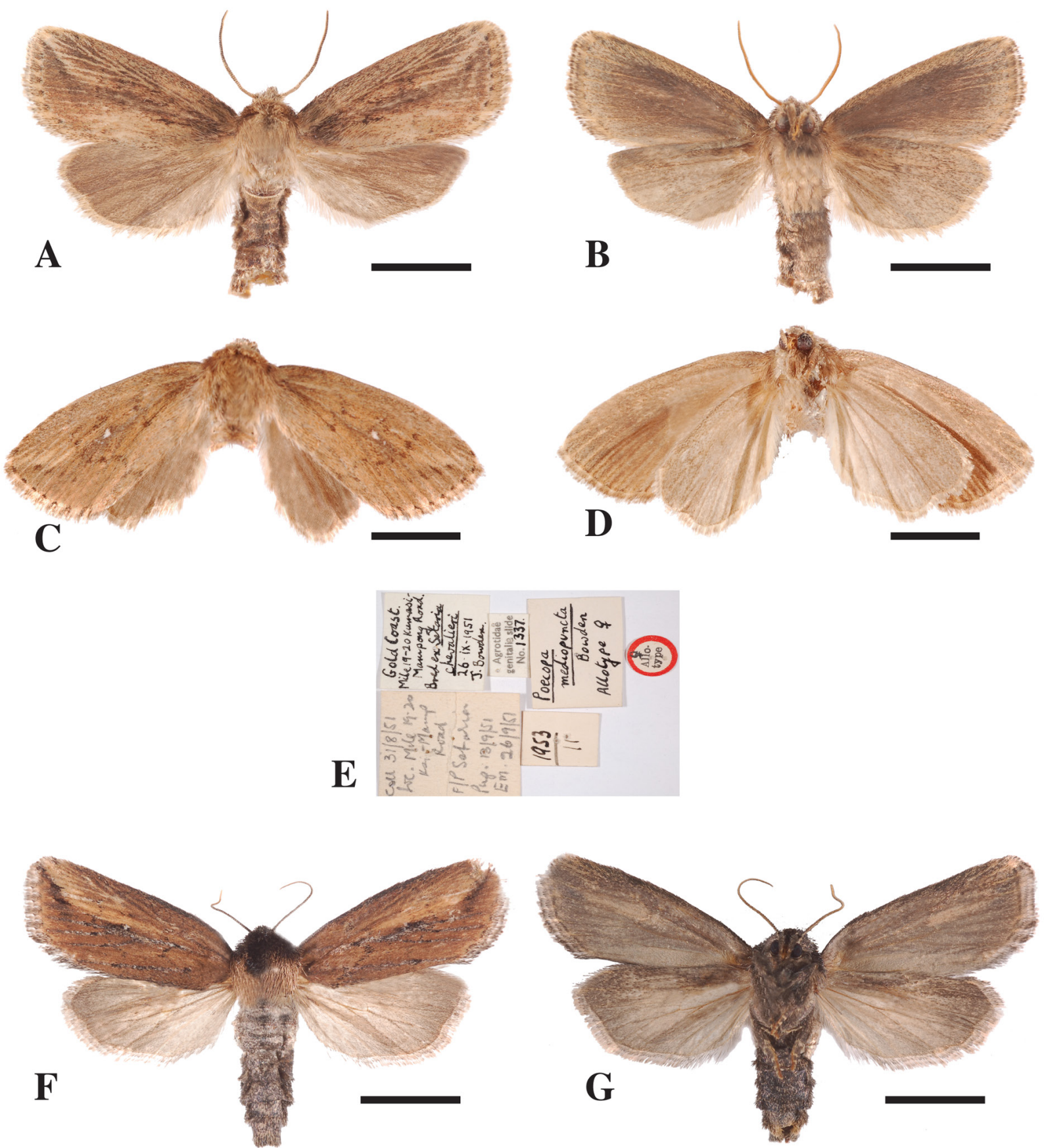

Fig. 7. Adults of species of Acrapex. - A-E. A. mediopuncta (Bowden, 1956). A. §, upper side. B. Ô, under side. C. $q$, upper side. D. $q$, under side. E. $\circ$, original labels from BMNH. - F-G. A. miscantha le Ru sp. nov. F., , upper side. G., , under side. Scale bars $=10 \mathrm{~mm}$. 


\section{Description (Fig. 7F-G)}

Antennae fuscous dorsally and ochreous ventrally, filiform; flagellum adorned dorsally with black scales, palpus fuscous, eyes black. Head and base of thorax black, thorax ochreous; legs fuscous suffused with white scales, ringed with white; abdomen fuscous, dorsally suffused with grey scales, black ventrally, suffused with grey scales.

FORE WING. Ground colour dark ochreous, suffused with fuscous, black and white scales, more heavily along veins and costal area; reniform indicated by few white scales, surrounded by some black scales; irrorated ochreous median area extended on distal side to termen; longitudinal grey median fascia along lower external margin of cell, ending obliquely at apex, adorned with two black elongated spots between veins; veins below cell adorned with grey, white and black scales; fringe grey white, slightly suffused with fuscous. Underside of fore wing with ground colour grey white, suffused with fuscous and some brown scales, more heavily on costa and close to termen.

HIND wING. Ground colour white, strongly suffused with fuscous scales; veins slightly irrorated with fuscous scales, costa and apex more heavily suffused with fuscous scales; fringe grey white, suffused with fuscous. Underside of hind wing grey-white, suffused with fuscous scales, but much more heavily on costa and apex; veins slightly irrorated with fuscous scales.

WingSPAN. $22 \mathrm{~mm}(1$ $)$.

Female genitalia (Fig. 3E). Corpus bursae elongated ovoid and globular, without signa; ductus seminalis from base of bursae; ductus bursae about one third length of corpus bursae, not sclerotised on bursa side, widening and sclerotised on ostial side; antrum narrow, band-like, slightly sclerotised, leaning on back and adorned with very narrow and strongly sclerotised plate divided in two in the middle. Ovipositor lobes relatively short (2 times as long as wide), with dorsal surface bearing numerous short and stout setae, apex of each lobe strongly curved and tooth-shaped.

\section{Bionomics}

Larvae were collected at the bottom of stems of $M$. violaceus growing in grasslands near marshes (Table 3 ); as many Acrapex species, $A$. miscantha sp. nov. is a markedly hygrophilous species. Unfortunately, no pictures were taken before pupation.

\section{Distribution}

Uganda. Only known from the holotype locality in Occidental Province close to Kyenjojo. This species was found in a mosaic of East African evergreen bushland and secondary Acacia wooded grassland (Mosaic \#45) (White 1983) (Fig. 4), belonging to the Congolian bioregion (Linder et al. 2012) (Fig. 5).

Acrapex parvaclara Berio, 1973

Figs 2G, O, 3F, 8A-D

Acrapex parvaclara Berio, 1973: 150-152, fig. 33.

Acrapex parvaclara - Poole 1989: 20 (catalogue).

\section{Diagnosis}

Male easily separated from males of other species of the group by the small rounded protuberance on each side of the apex of the juxta and by the small curved, hand-shaped vesica (Fig. 2G, O); female easily separated from females of other species of the group by the strongly sclerotized antrum, with a 
large, broad ventral plate, slightly bilobate, widening to the front, the anterior part shaped like a thin lip, the posterior part concave (Fig. 3F).

\section{Material examined}

\section{Holotype}

DEMOCRATIC REPUBLIC OF THE CONGO: §, North Kivu, Ngesho, Sep. 1937, J. Ghesquière leg. (MRAC, gen. prep. Berio N 3755).

\section{Paratypes}

DEMOCRATIC REPUBLIC OF THE CONGO: 2 $ぇ$, Sankuru, Dimbelenge, Apr. 1951, Dr Fontaine leg. (MNHN); 1 ð̊, Sankuru, Lac Hukauda, Nov. 1951, Dr Fontaine leg. (MNHN); 1 ô, Kindu, Dr Russo leg. (MNHN); 1 đ̃, Katanga, Kimbai, Dec. 1925, Ch. Seydel leg. (MCSN).

\section{Other material}

CAMEROON: 1 क, Northwest Region, Babessi, 0601.926' N, 10³3.112' E, 1203 m a.s.1., Dec. 2013,

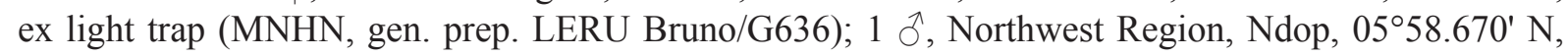
$10^{\circ} 24.410^{\prime}$ E, $1182 \mathrm{~m}$ a.s.1., 4 Dec. 2013, ex light trap (MNHN, gen. prep. LERU Bruno/G605).

UGANDA: 1 đૈ, Kalinzu Forest, T.H.E. Jackson leg., B.M.E Afr. Exp. B.M. 1985-203 (BMNH, Noctuidae genitalia slide 2466); 1 q, South Buganda Region, Katonga, $00^{\circ} 01.577^{\prime} \mathrm{S}, 32^{\circ} 00.958^{\prime} \mathrm{E}$, $1151 \mathrm{~m}$ a.s.1., 28 May 2014, ex light trap (MNHN, gen. prep. LERU Bruno/G715); 3 + , Western Region, Itojo, $00^{\circ} 50.546^{\prime} \mathrm{N}, 30^{\circ} 13.131^{\prime} \mathrm{E}, 1070 \mathrm{~m}$ a.s.1., 22 May 2014, ex light trap (MNHN, gen. prep. LERU Bruno/G713); 1 + , Western Region, Kanga-Bukama, 00²12.898' S, 3005.624' E, 1277 m a.s.l., 21 May 2014, ex light trap (MNHN, gen. prep. LERU Bruno/G712).

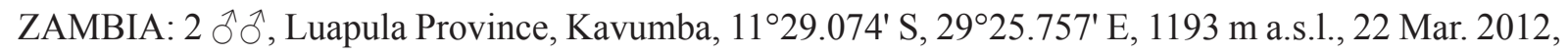
ex light trap (MNHN, gen. prep. LERU Bruno/G157).

\section{Redescription (Fig. 8A-D)}

Both sexes look similar; however, the general shape of the female fore wing is more elongated at the apex than in the male and fore wings are also paler in females; antennae ochreous, filiform in female, slightly ciliate in male; flagellum fuscous, adorned dorsally with black scales, palpus fuscous, eyes brown. Head and base of thorax fuscous, thorax ochreous; legs ochreous, ringed with white; abdomen fuscous, suffused with grey scales.

FORE WING. Ground colour ochreous, suffused with fuscous, black and white scales, more heavily along veins and costal area; reniform indicated by few white scales, surrounded by some black scales; row of black elongated spots on veins in front of reniform; longitudinal fuscous median fascia along lower external margin of cell, ending obliquely at apex; veins below cell adorned with fuscous scales; row of black elongated spots between veins on margin; fringe white, slightly suffused with fuscous. Underside of fore wing with ground colour ochreous, strongly suffused with fuscous and some brown scales, more heavily on costa and close to termen.

HIND wING. Ground colour white in female, white ochreous in male, suffused with fuscous scales; veins slightly irrorated with fuscous scales, costa and apex more heavily suffused with fuscous scales; fringe white, suffused with fuscous. Underside of hind wing white, suffused with fuscous scales, but much more heavily on costa and apex; veins slightly irrorated, with fuscous scales.

WINGSPAN. 18-22 mm (5 ふぶ); 23-25 mm (5 우). 

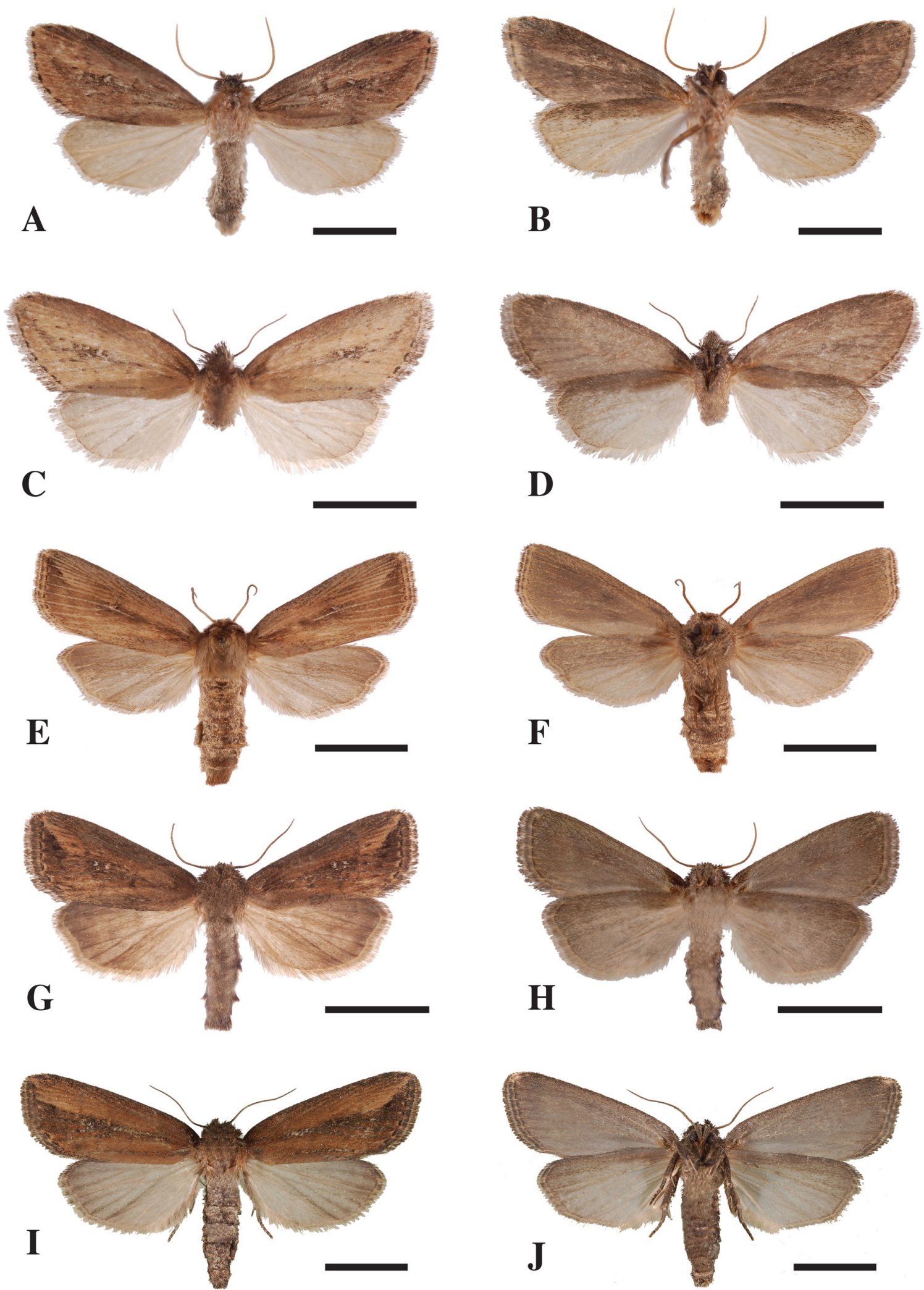

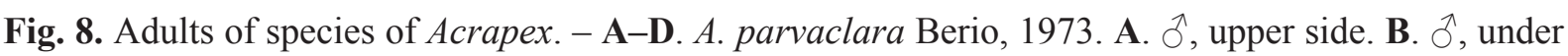

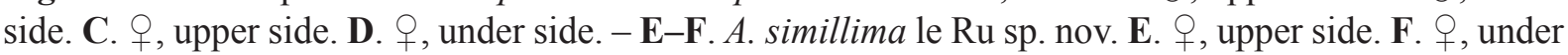

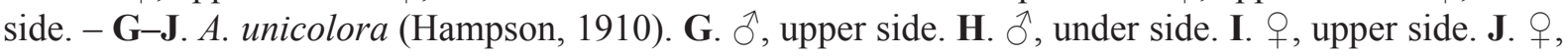
under side. Scale bars $=10 \mathrm{~mm}$. 
Male genitalia (Fig. 2G, O). Uncus long, widening in distal third, tapering in truncate apex, tufted with long hairs on upper side. Tegumen with medium-sized rounded penniculi, vinculum pointed, with medium-sized triangular saccus, valves short and broad, cucullus rounded and tufted with medium-sized hairs, coastal margin slightly broadened on inner side and produced into strong, tooth-shaped spine, sclerotized at apex, pointed and slightly curved inwardly; juxta large, plate-like, base slightly flattened, without sclerotization, with long and widening bilobate neck, ending on each side with small, rounded protuberance. Aedeagus short, slightly curved, with two lateral areas adorned with short setae; curved, hand-shaped vesica with basal tuft of needle-shaped cornutus, pointed obliquely downward.

FEMALE Genitalia (Fig. 3F). Corpus bursae long and globular, without signum; ductus bursae very short, with strongly sclerotised funnel-shaped connection with ostium; antrum strongly sclerotized, with large, broad ventral plate, slightly bilobate, widening to the front, anterior part shaped like thin lip, posterior part concave; dorsal plate small, weakly sclerotized. Ovipositor lobes relatively short (2 times as long as wide), with bluntly pointed apex, dorsal surface bearing numerous short and stout setae.

\section{Bionomics}

Biology unknown. The moths were caught in a light trap in grasslands near woodlands.

\section{Distribution}

Cameroon, the Democratic Republic of the Congo, Uganda and Zambia. Known from several localities at medium altitude between 1000 and $1200 \mathrm{~m}$ a.s.l. Moths were found in a mosaic of lowland rainforest and secondary grassland (Mosaic \#11) and from a mosaic of Zambezian dry evergreen forest and wetter miombo woodland (Mosaic \#21) (White 1983) (Fig. 4), belonging to the Congolian and to the Zambezian bioregion respectively (Linder et al. 2012) (Fig. 5).

Acrapex simillima Le Ru sp. nov. urn:1sid:zoobank.org:act:336CE140-8928-451F-A33F-CC74CBBEF930

Figs 3G, 8E-F, 9A

\section{Diagnosis}

Female easily separated from females of other species of the group by the sclerotized, band-like ventral plate, strongly concave on the front (Fig. 3G).

\section{Etymology}

The species epithet refers to the close similarity of the wing pattern with that of $A$. mediopuncta (Bowden, 1956).

\section{Material examined}

Holotype

UGANDA: + , Southern Region, Kayanga Forest, $00^{\circ} 22.027^{\prime}$ S, 3006.722' E, 1447 m a.s.1., 6 Apr. 2006, ex larva (in stem of Setaria megaphylla (Steud) Dur. \& Schinz.), B. Le Ru leg. (MNHN, gen. prep. LERU Bruno/G69).

\section{Paratypes}

KENYA: 2 우, Western Province, Kakamega Forest, $00^{\circ} 22.530^{\prime} \mathrm{N}, 34^{\circ} 53.660^{\prime}$ E, $1430 \mathrm{~m}$ a.s.1., May 2007, ex larva (in stem of Setaria megaphylla), B. Le Ru leg. (MNHN, gen. prep. LERU Bruno/G31).

UGANDA: 3 $q$, , same date and locality as holotype, ex light trap, B. Le Ru leg. (MNHN, gen. prep. LERU Bruno/G32, G770). 


\section{Description (Fig. 8E-F)}

Antennae ochreous, filiform; flagellum ochreous, palpus ochreous, eyes black. Head and base of thorax brown, thorax ochreous; legs brown, suffused with ochreous scales, ringed with ochreous; abdomen ochreous, suffused with fuscous scales.

FORE WING. Ground colour bright ochreous, suffused with dark ochreous and fuscous scales, more heavily between veins and on costal area; reniform indicated by few white scales, surrounded by some black scales; longitudinal brown median fascia along lower external margin of cell, ending obliquely at apex, adorned with two black elongated spots between veins; row of black elongated spots between veins on margin; fringe ochreous, suffused with brown. Underside of fore wing with ground colour ochreous, heavily suffused with fuscous and brown scales.

HIND wING. Ground colour grey white, strongly suffused with fuscous scales, more heavily on costa and apex; veins slightly irrorated, with fuscous scales; fringe grey white, suffused with fuscous. Underside of hind wing grey white, suffused with fuscous scales, but much more heavily on costa and apex; veins slightly irrorated, with fuscous scales.

WingSPAN. 26-32 mm (7 우).

LARVAL L5 InSTAR (Fig. 9A). Length 20-25mm, width $2.5 \mathrm{~mm}$; head smooth, black, prothoracic shield brown; body with ground colour dark pink, pinacula and caudal plate black. Young larvae very similar to mature ones.

Female genitalia (Fig. 3G). Corpus bursae elongated, ovoid and globular, without signa; ductus seminalis from base of bursae; ductus bursae about less than half length of corpus bursae, not sclerotised on bursa side, widening and slightly sclerotised on ostial side; antrum ovoid, with sclerotized, band-like ventral plate, strongly concave on front; ovipositor lobes relatively short (2 times as long as wide), with bluntly pointed apex, dorsal surface bearing numerous short and stout setae.

\section{Bionomics}

Acrapex simillima sp. nov. is a markedly forest species, inhabiting open patches of grasses along forest roads. Larvae were all collected at the bottom of young stems of $S$. megaphylla (Table 3) and were always solitary. Typically, plants exhibiting signs of infestation by A. simillima sp. nov. larvae have a curled, brown central leaf. One pupa was found in a stem; however, as in most species of Acrapex, most larvae probably pupate in the soil near exit holes.

\section{Distribution}

Kenya and Uganda. The records are from Guineo-Congolian rain forests (Mosaic \#1) (White 1983) (Fig. 4), belonging to the Congolian bioregion (Linder et al. 2012) (Fig. 5).
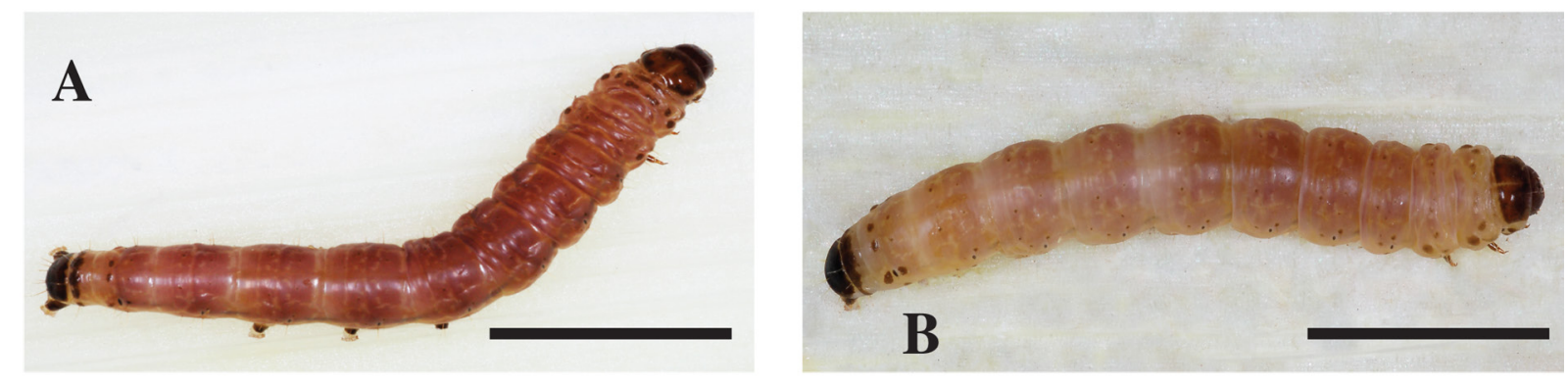

Fig. 9. Last instar larva. A. Acrapex simillima le Ru sp. nov. B. A. unicolora (Hampson, 1910). Scale bar $=10 \mathrm{~mm}$. 
Acrapex unicolora (Hampson, 1910)

Figs 2H, P, 3H, 8G-J, 9B

Calamistis unicolora Hampson, 1910: 279, pl. 143, fig. 12.

Acrapex brunneosa Bethune-Baker, 1911: 517.

Busseola hemiphlebia Hampson, 1914: 161.

Busseola fuscantis Hampson, 1918: 153.

Acrapex simplex Janse, 1939: 359.

Acrapex quadrata Berio, 1973: 150, fig. 35.

Acrapex brunneosa - Poole 1989: 19 (catalogue).

Busseola fuscantis - Poole 1989: 181 (catalogue).

Acrapex hemiphlebia - Poole 1989: 20 (recombination, catalogue).

Acrapex quadrata - Poole 1989: 20 (catalogue).

Acrapex simplex - Poole 1989: 21 (catalogue).

Acrapex unicolora - Poole 1989: 21 (recombination, catalogue).

\section{Diagnosis}

Male easily separated from males of other species of the group by the pointed apex of the uncus, the ridge-like, roundly pointed expansion of the coastal margin and by the aedeagus having no vesica (Fig. 2H, P); female easily separated from females of other species of the group by the ductus bursae, which are widening and sclerotised on the ostial side, and by the narrow, band-like, slightly sclerotised antrum (Fig. 3H).

\section{Material examined}

\section{Holotype}

DEMOCRATIC REPUBLIC OF THE CONGO: đ’, Upper Congo, 1907, A.F.R. Wollaston leg. (BMNH 1907-269, Agrotidae genitalia slide 1458).

\section{Other material}

ANGOLA: 2 ふふ઼, N'Dalla Tando, N Angola, 2700 ft, 26 Nov. 1908, Dr W.J. Ansorge leg. (BMNH, Noctuidae genitalia slide 2480).

DEMOCRATIC REPUBLIC OF THE CONGO: $\widehat{\partial}$, holotype of A. quadrata, Sankuru, Dimbelenge, 25 Nov. 1950, Dr M. Fontaine leg. (MRAC, adult; MCSN, genitalia, Berio, E prep N.3753).

MALAWI: 1 , Mt Mlanje, Nyasaland, 30 Jun. 1913, S.A. Neave leg. (BMNH 1914-171, Agrotidae genitalia slide No 1345); 5 ડ̄ $\widehat{\jmath}$, Mt Mlanje, Nyasaland, 26 Mar. 1913, S.A. Neave leg. (BMNH 1914171); 1 đ̊, Luchenya River, Mlanje, Nyasaland, 26 Mar. 1913, S.A. Neave leg. (BMNH 1914-171).

NIGERIA: ${ }^{\Uparrow}$, holotype of A. hemiphlebia, Kateregi, 12 Sep. 1910, Scott Macfie leg. (BMNH, 1911-269, Agrotidae genitalia slide No 1460).

TANZANIA: 2 우, Iringa Region, Kifanya, 09³3.443' S, 3506.246' E, 1675 m a.s.1., 22 Mar. 2007, ex larva (in stem of Andropogon gayanus Kunth), B. Le Ru leg. (MNHN, gen. prep. LERU Bruno/

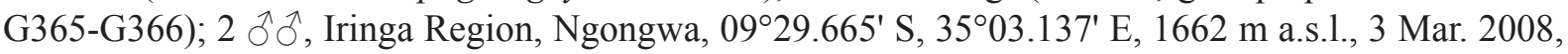
ex larva (in stem of Andropogon gayanus Kunth), B. Le Ru leg. (MNHN, gen. prep. LERU Bruno/ G364-G474).

REPUBLIC OF THE CONGO: 1 ð, Kouilou Department, Lac Nanga, 0431.005' S, $12^{\circ} 04.172^{\prime}$ E, 35 m a.s.1., 17 Apr. 2013, ex light trap, B. Le Ru leg. (MNHN, gen. prep. LERU Bruno/G538); 2 $\widehat{\jmath}$, 


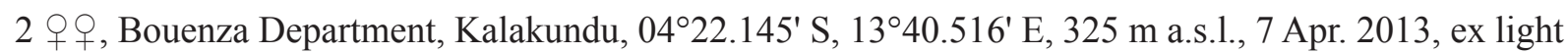
trap, B. Le Ru leg. (MNHN, male gen. prep. LERU Bruno/G577, female gen. prep. LERU Bruno/G576).

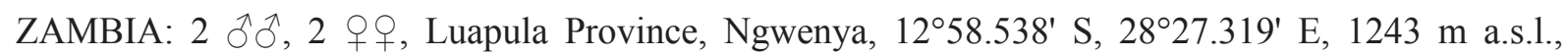
21 Mar. 2012, ex light trap, B. Le Ru leg. (MNHN, male gen. prep. LERU Bruno/G174, female gen.

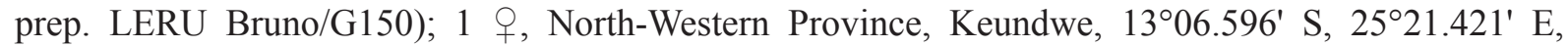
1225 m a.s.l., 19 Mar. 2012, ex light trap, B. Le Ru leg. (MNHN, gen. prep. LERU Bruno/G158); 1 ð, 1 q, Central Province, Khaembe, 14³3.107' S, 28¹9.301' E, $1191 \mathrm{~m}$ a.s.l., 15 Mar. 2012, ex light trap, B. Le Ru leg. (MNHN, male gen. prep. LERU Bruno/G170, female gen. prep. LERU Bruno/G171).

ZIMBABWE : 1 đ, Bulawayo Dist., 16 Jan. 1918, ex light trap, A.J.T. Janse leg. (PM, gen. prep. 3370).

\section{Redescription (Fig. 8G-J)}

The sexes look similar; however, the general shape of the female fore wing is more elongated at the apex than in the male; antennae fuscous, filiform in female and slightly ciliate in male; flagellum fuscous, adorned with grey scales, palpus fuscous, suffused with grey scales, eyes fuscous brown. Head and base of thorax brown, thorax dark ochreous; legs brown, suffused with grey scales, ringed with grey; abdomen fuscous, suffused with grey scales.

FORE WING. Ground colour dark ochreous, suffused with fuscous and black scales, more heavily along veins, termen and costal area; reniform indicated by few white scales, surrounded by some brown scales; row of black elongated spots on veins in front of reniform; longitudinal brown median fascia along lower external margin of cell, ending obliquely at apex; veins below cell adorned with fuscous brown and white scales; row of black elongated spots between veins on margin; fringe fuscous, slightly suffused with brown. Underside of fore wing with ground colour grey, suffused with fuscous scales, more heavily on costa and close to termen.

HIND wING. Ground colour white in female, white ochreous in male, heavily suffused with fuscous scales in male; veins heavily irrorated, with fuscous scales, costa and apex more heavily suffused with fuscous scales; fringe grey, suffused with fuscous. Underside of hind wing grey, suffused with fuscous scales, but much more heavily on costa and apex; veins slightly irrorated, with fuscous scales.

WingSPAN. 20-23 mm (8 ふふ); 22-28 mm (7 ゚゚).

LARVAL L5 INSTAR (Fig. 9B). Length 20-25 mm, width $2.5 \mathrm{~mm}$; head smooth, dark brown, prothoracic shield brown; body with ground colour pink, pinacula and caudal plate dark brown. Young larvae very similar to mature ones.

Male genitalia (Fig. 2H, P). Uncus long, widening in distal third, tapering in pointed apex, tufted with long hairs on upper side. Tegumen with medium-sized rounded penniculi, vinculum pointed, with medium-sized triangular saccus, valves short and broad, cucullus rounded and tufted, with mediumsized hairs, coastal margin slightly broadened on inner side and produced into ridge-like expansion, roundly pointed and slightly curved inwardly; large juxta, plate-like, base slightly flattened, without sclerotization, with long and widening neck, slightly bilobate at apex, ending on each side with rounded expansion; aedeagus short, slightly curved.

Female genitalia (Fig. 3H). Corpus bursae elongated, ovoid, without signa; ductus bursae about onethird length of corpus bursae, not sclerotised on bursa side, widening and sclerotised on ostial side. Antrum narrow, band-like, slightly sclerotised. Ovipositor lobes short (2 times as long as wide), with bluntly pointed apex, dorsal surface bearing numerous short and stout setae. 


\section{Bionomics}

Acrapex unicolora is a markedly hygrophilous species of banks of streams, rivers and marshes. Larvae were collected in Tanzania from A. gayanus, Chrysopogon zizanoides (L.) Roberty, Cymbopogon schoenanthus subsp. proximus (Hochst. ex A.Rich.) Maire \& Weller, Cymbopogon pospischilii (K. Schum.) C.E.Hubb., Hyparrhenia diplandra (Hack.) Stapf and S. sphacelata (Schumach.) Moss (Table 3). Larvae were collected at the bottom of young stems and were always solitary. Typically, plants exhibiting signs of infestation by A. unicolora larvae have a curled, brown central leaf. No pupae were found in stems and therefore borers probably pupate in the soil near exit holes.

\section{Distribution}

Angola, the Democratic Republic of the Congo, Malawi, Nigeria, the Republic of the Congo, Tanzania, Zambia and Zimbabwe. Known from many localities from sea level to $2147 \mathrm{~m}$ a.s.l. Moths were found in a mosaic of lowland rain forest and secondary grassland (Mosaic \#11A), a mosaic of Zambezian dry evergreen forest and wetter miombo woodland (Mosaic \#21), wetter Zambezian miombo woodland (Mosaic no 25) and undifferentiated montane vegetation (Mosaic \#19) (White 1983) (Fig. 4), belonging to the Congolian and to the Zambezian bioregion, respectively (Linder et al. 2012) (Fig. 5).

\section{Remarks}

It is worth highlighting that the records of Acrapex hemiphlebia by Janse (1939) correspond to specimens from a different species that is not yet described and related to Acrapex albivena Hampson, 1910.

\section{Phylogenetic and molecular species delimitation analyses}

Maximum likelihood analyses performed with IQ-TREE yielded a well-supported topology (49 of the 70 nodes supported by BV $\geq 70 \%$; see Fig. 10), especially when considering interspecific relationships (17 of the corresponding 18 nodes supported by $\mathrm{BV} \geq 70 \%$ ). The only representative of $A$. mediopuncta (formerly P. mediopuncta) is recovered in a derived position among other members of the genus Acrapex. Members of the A. albivena species group are recovered as sister to the unicolora group (A. albivena, A. salmona, A. sporobola, A. syscia and A. yakoba), with a high support (BV of $96 \%$ ), while the only representative of the stygiata species group (A. stygiata) is found as sister to both the albivena and unicolora group (BV of 100\%).

Results of the PTP molecular species delimitation are congruent with the results of the morphological study. Interestingly, PTP analyses highlight the existence of a potential new species refered to as Acrapex sp. SECOG7537 (Fig. 10). This specimen corresponds to a unique larva collected in the Republic of the Congo on Pennisetum unisetum (Nees) Benth.

\section{Discussion}

The ten species treated here make up a morphologically homogeneous group; this contradicts the statement made by Tams \& Bowden (1953) about the isolation of the genus Poecopa. Indeed, the male genitalia of $A$. mediopuncta show the typical male characteristics of the A. unicolora group, namely the short and broad valves, the coastal margin slightly broadened on the inner side and produced into a spine and the short and stout aedeagus with a hand-shaped vesica with needle-shaped cornutus. The synonymy of Poecopa with Acrapex at the generic level is also entirely supported by the results of the phylogenetic analyses, which recover $A$. mediopuncta in a derived position within the clade encompassing all A. unicolora representatives. Although the ten species revised and described here present a very similar wing pattern and colour, they are easily separated with both male and female genitalia; the vesica is the most useful character to identify the males and the ventral plate of the antrum allows a clear identification of the different females. However the group is composed of two ecological sub-groups, with 


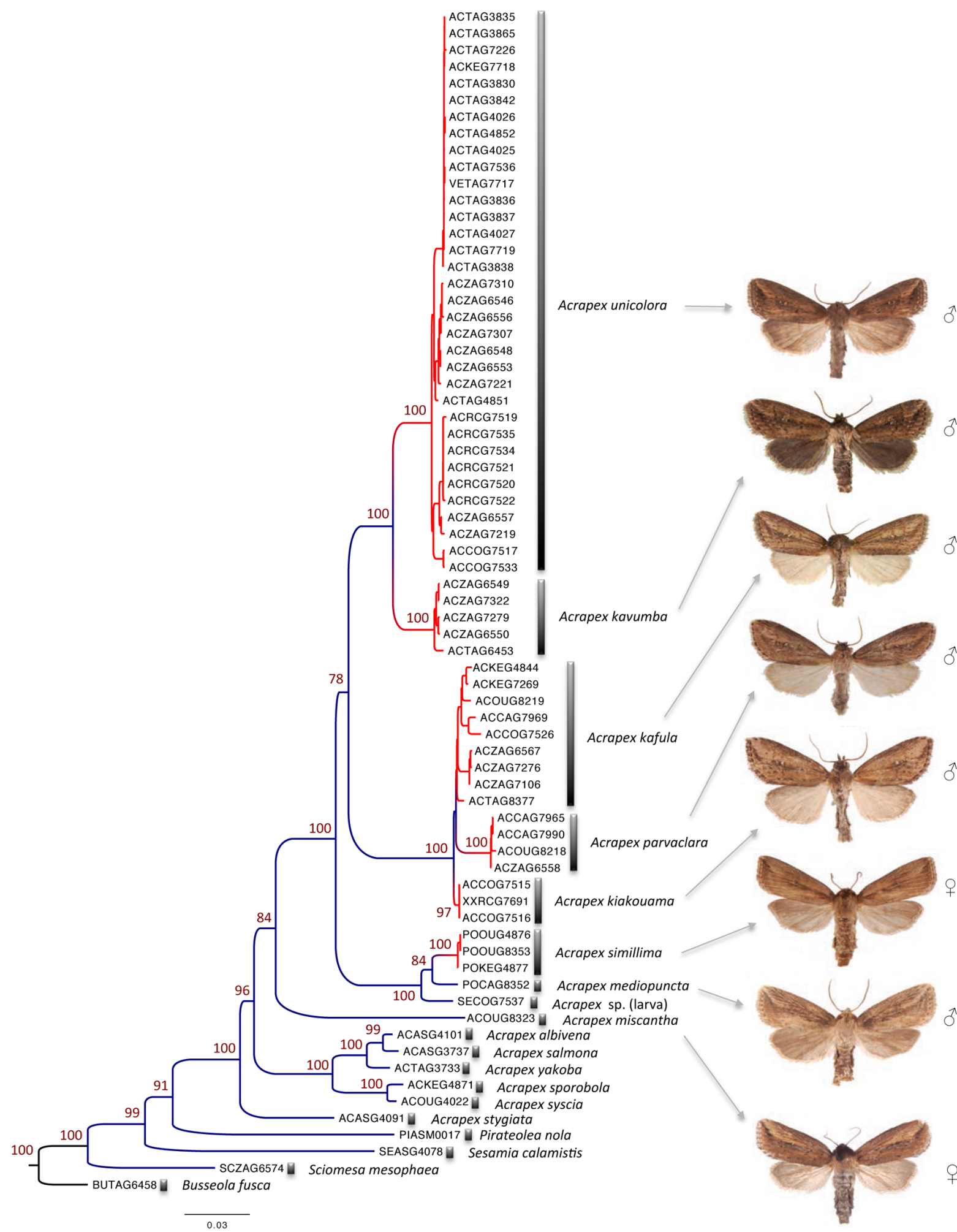

Fig. 10. Maximum likelihood tree resulting from the analysis of the combined dataset carried out with IQ-TREE. Support of major nodes is displayed as BV (only BV $>50 \%$ are shown). On the right, corresponding adult habitus (for species belonging to the A. unicolora species group) are also included for illustrative purposes. Results of PTP analyses are figured using coloured branches and vertical side bars. Putative molecular species clusters are indicated using transitions between blue-coloured branches to red-coloured branches (vertical bars are also informative). 
A. mediopuncta and A. simillima sp. nov. as markedly forest species inhabiting open patches of grasses in Guineo-Congolian rain forests of the Congolian bioregion and all the other species markedly hygrophilous of banks of streams, rivers and marshes in Zambezian miombo woodland belonging to the Zambezian bioregion. While A. unicolora, A. kafula sp. nov. and A. parvaclara are recorded from East Africa to western areas of Central Africa, our results suggest restricted distributions for all six other species. Despite extensive surveys in more than 16 sub-Saharan countries, we did not collect any species of the A. unicolora group in the Southern or Somalian Bioregions (Linder et al. 2012).

We report here for the first time a host-plant association of $A$. unicolora to different species of Andropogonae and to one Panicae, S. sphacelata, and of A. miscantha sp. nov. to another Andropogonae, $M$. violaceus. The potential new species collected in the Republic of the Congo was also reared from another species of Andropogoneae, Pennisetum unisetum. Although we did not record any host plant association for other species of the group, considering that the grasses of the miombo woodland are normally members of the Andropogonae (McClanahan \& Young 1996), we can hypothetize that most of the species should be associated to species of that tribe. This is also consistent with the pattern of hostplant associations that were demonstrated for other species of Acrapex (the albivena and stygiata species groups), which were exclusively reared from Andropogoneae (Le Ru et al. 2014).

As all recorded Acrapex larvae, the four Acrapex species of the A. unicolora group collected in the field as larvae came from host plants belonging to the Sesamia-like species as defined by Le Ru et al. (2006b). They are morphologically similar, with ground colour pinkish buff, without any markings. The feeding habits of the four species are similar, with the typical symptom of plant attack being death of the central tiller, often referred to as 'dead heart'. In addition, as for Acrapex spp. (Le Ru et al. 2014), we always found the larvae solitary in the stems. We speculate that Acrapex larvae typically fed on more than one stem before completing their development. We suspect that the larvae disperse when they reach the fourth instar. No pupae were found in stems, and therefore borers probably pupate in the soil.

\section{Acknowledgments}

We thank the curators of BMNH (M. Honey) and MCSN (F. Rigato) for the permission to study and photograph the types. We are grateful to the Boyekoli Ebale Congo Expedition, organized in 2010 by a consortium of three Belgian institutions - the Royal Museum of Central Africa, the Royal Belgian Institute of Natural Sciences and the National Botanical Garden of Belgium - in collaboration with the University of Kisangani (UNIKIS) in the Democratic Republic of the Congo, who allowed us to participate in the expedition and collect many interesting specimens. Financial support was provided by the Institut de Recherche pour le Développement, by icipe, African Insect Science for Food and Health (Kenya) and by the "Bibliothèque du Vivant" ("Library of Life") program (Project Noctuid Stem Borer Biodiversity; NSBB), supported by a joint CNRS, INRA and MNHN consortium. Laboratory facilities were provided by icipe, African Insect Science for Food and Health (Kenya) and the UMR EGCE (formerly the Evolution Génomes Spéciation laboratory) in Gif-sur-Yvette, France. The authors also thank Alexandre Dehne Garcia for his help at the CBGP HPC computational facility. All specimens were collected under appropriate collection permits from the six countries recorded and no conflicts of interest were discovered.

\section{References}

Astrin J.J., Stüben P.E., Misof B., Wägele J.W., Gimnich F., Raupach M.J. \& Ahrens D. 2012. Exploring diversity in cryptorhynchine weevils (Coleoptera) using distance-, character- and tree-based species delineation. Molecular Phylogenetics and Evolution 63: 1-14. http://dx.doi.org/10.1016/j. ympev.2011.11.018 
LE RU B. et al., Contribution to Acrapex systematics

Berio E. 1973. Nuove species e generi di Noctuidae africane e asiatiche e note sinonimiche. Parte II. Annali del Museo Civico di Storia Naturale "Giacomo Doria” 79: 126-171.

Bowden J. 1956. New species of African stem-boring Agrotidae (Lepidoptera). Bulletin of Entomological Research 47: 415-428.

Dumas P., Barbut J., Le Ru B., Silvain J.-F., Clamens A.-L., d'Alençon E. \& Kergoat G.J. 2015. Phylogenetic molecular species delimitations unravel potential new species in the pest genus Spodoptera Guenée, 1852 (Lepidoptera, Noctuidae). PLoS One 10: e0122407. http://dx.doi.org/10.1371/journal. pone.0122407

Fletcher D.S. 1961. Noctuidae. In: Evans G.O \& Fletcher D.S. (eds) Ruwenzori Expedition 1952. Vol. 1: 177-323. British Museum (Natural History), London.

Hampson G.F. 1894. The Fauna of British India, including Ceylon and Burma. Moths. Taylor \& Francis, London.

Hampson G.F. 1910. Catalogue of the Lepidoptera Phalaenae in the Collection of the British Museum (Nat. Hist.). IX. Noctuidae. Taylor and Francis, London.

Hampson G.F. 1914. Descriptions of new genera and species of Noctuidae. Annals and Magazine of Natural History 13: 146-175, 197-223. http://dx.doi.org/10.1080/00222931408693462

Hillis D.M. \& Bull J.J. 1993. An empirical test of bootstrapping as a method for assessing confidence in phylogenetic analysis. Systematic Biology 42: 182-192. http://dx.doi.org/10.1093/sysbio/42.2.182

Janse A.J.T. 1939. The Moths of South Africa. Volume 3. Cymatophoridae, Callidulidae and Noctuidae. E.P. and Commercial Printing Co. Ltd, Durban.

Katoh K. \& Standley D.M. 2013. MAFFT multiple sequence alignment software version 7: improvements in performance and usability. Molecular Biology and Evolution 30: 772-780. http://dx.doi.org/10.1093/ $\underline{\mathrm{molbev} / \mathrm{mst} 010}$

Kergoat G.J., Prowell D.P., Le Ru B.P., Mitchell A., Dumas P., Clamens A.-L., Condamine F.L. \& Silvain J.-F. 2012. Disentangling dispersal and vicariance patterns in armyworms: evolution and historical biogeography of the pest genus Spodoptera (Lepidoptera: Noctuidae). Molecular Phylogenetics and Evolution 65: 855-870. http://dx.doi.org/10.1016/j.ympev.2012.08.006

Lanfear R., Calcott B., Ho S.Y.W. \& Guindon S. 2012. PartitionFinder: combined selection of partitioning schemes and substitution models for phylogenetic analyses. Molecular Biology and Evolution 29: 1695701. http://dx.doi.org/10.1093/molbev/mss020

Le Ru B.P., Ong'amo G.O., Moyal P., Muchungu E., Ngala L., Musyoka B., Abdullah Z., MatamaKauma T., Lada V.Y., Pallangyo B., Omwega C.O., Schulthess F., Calatayud P.-A. \& Silvain J.-F. 2006a. Geographic distribution and host plant ranges of East African noctuid stem borers. Annales de la Société Entomologique de France 42: 353-361.

Le Ru B., Ong'amo G.O., Moyal P., Ngala L., Musyoka B., Abdullah Z., Cugala D., Defabachew B., Haile T.A., Kauma Matama T., Lada V.Y., Negassi B., Pallangyo K., Ravololonandrianina J., Sidumo A., Omwega C., Schulthess F., Calatayud P.-A. \& Silvain J.-F. 2006b. Diversity of lepidopteran stem borers on monocotyledonous plants in eastern Africa and the islands of Madagascar and Zanzibar revisited. Bulletin of Entomological Research 96: 555-563. http://dx.doi.org/10.1079/BER2006457

Le Ru B.P., Capdevielle-Dulac C., Toussaint E.F.A., Conlong D., Van den Berg J., Pallangyo B., Ong'amo G., Chipabika G., Molo R., Overholt W.A., Cuda J.P. \& Kergoat G.J. 2014. Integrative taxonomy of Acrapex stem borers (Lepidoptera: Noctuidae: Apameini). Invertebrate Systematics 28: 451-475. http://dx.doi.org/10.1071/IS13062 
Le Ru B.P., Capdevielle-Dulac C., Conlong D., Pallangyo B., Van den Berg J., Ong'amo G. \& Kergoat G.J. 2015. A revision of the genus Conicofrontia Hampson (Lepidoptera, Noctuidae, Apameini, Sesamiina), with description of a new species: new insights from morphological, ecological and molecular data. Zootaxa 3925: 56-74. http://dx.doi.org/10.11646/zootaxa.3925.1.4

Linder H.P., de Klerk H.M., Born J., Burgess N.D., Fjeldsa J. \& Rahbek C. 2012. The partitioning of Africa: statistically defined biogeographical regions in sub-Saharan Africa. Journal of Biogeography 39: 1189-1205. http://dx.doi.org/10.1111/j.1365-2699.2012.02728.x

Matama-Kauma T., Schulthess F., Le Ru B., Mueke J.M., Ogwang J.A. \& Omwega C.O. 2008. Abundance and diversity of lepidopteran stemborers and their parasitoids on selected wild grasses in Uganda. Crop Protection 27: 505-513. http://dx.doi.org/10.1016/j.cropro.2007.08.003

McClanahan T.R. \& Young T.P. 1996. East African Ecosystems and their Conservation. Oxford University Press, New York.

Minh B.Q., Nguyen M.A. \& von Haeseler A. 2013. Ultrafast approximation for phylogenetic bootstrap. Molecular Biology and Evolution 30: 1188-1195. http://dx.doi.org/10.1093/molbev/mst024

Moolman J., Van den Berg J., Conlong D., Cugala D., Siebert S. \& Le Ru B. 2014. Species diversity and distribution of lepidopteran stem borers in South Africa and Mozambique. Journal of Applied Entomology 138: 52-66. http://dx.doi.org/10.1111/jen.12085

Ndemah R., Schulthess F., Le Ru B. \& Bame I. 2007. Lepidopteran cereal stemborers and associated natural enemies on maize and wild grass hosts in Cameroon. Journal of Applied Entomology 131: 658668. http://dx.doi.org/10.1111/j.1439-0418.2007.01219.x

Nguyen L.T., Schmidt H.A., von Haeseler A. \& Minh B.Q. 2015. IQ-TREE: a fast and effective stochastic algorithm for estimating maximum likelihood phylogenies. Molecular Biology and Evolution 32: 268-274. http://dx.doi.org/10.1093/molbev/msu300

Nylander J.A.A., Ronquist F., Huelsenbeck J.P. \& Nieves-Aldrey J.L. 2004. Bayesian phylogenetic analysis of combined data. Systematic Biology 53:47-67.http://dx.doi.org/10.1080/10635150490264699

Ong'amo G.O., Le Ru B., Dupas S., Moyal P., Calatayud P.-A. \& Silvain J.-F. 2006. The role of noncrop hosts on population dynamics of lepidopteran stemborer pests along altitudinal gradient in Kenya. Annales de la Société Entomologique de France 42: 363-370.

Ong' amo G.O., Le Ru B., Calatayud P.-A. \& Silvain J.-F. 2013. Composition of stem borer communities in selected vegetation mosaics in Kenya. Arthropod-Plant Interactions 7: 267-275.

Ong'amo G.O., Le Gall P., Ndemah R. \& Le Ru B.P. 2014. Diversity and host range of lepidopteran stem borer species in Cameroon. African Entomology 22: 625-635.

Onyango F.O. \& Ochieng'Odero J.P.R. 1994. Continuous rearing of the maize stem borer Busseola fusca on an artificial diet. Entomologia Experimentalis et Applicata 73: 139-144. http://dx.doi. org/10.1111/j.1570-7458.1994.tb01848.x

Poole R.W. 1989. Lepidopterorum Catalogus (New Series, Fasc. 118). CRC Press, Boca Raton, FL.

Ripplinger J. \& Sullivan J. 2008. Does choice in model selection affect maximum likelihood analysis? Systematic Biology 57: 76-85. http://dx.doi.org/10.1080/10635150801898920

Tams W.H.T. \& Bowden J. 1953. A revision of the African species of Sesamia Guenée and related genera (Agrotidae-Lepidoptera). Bulletin of Entomological Research 43: 645-678. http://dx.doi.org/10.1017/ $\underline{\text { S0007485300026717 }}$ 
Tang C.Q., Humphreys A.M., Fontaneto D. \& Barraclough T.G. 2014. Effects of phylogenetic reconstruction method on the robustness of species delimitation using single-locus data. Methods in Ecology and Evolution 5: 1086-1094. http://dx.doi.org/10.1111/2041-210X.12246

Toussaint E.F.A., Condamine F.L., Kergoat G.J., Silvain J.-F., Capdevielle-Dulac C., Barbut J. \& Le $\mathrm{Ru}$ B.P. 2012. Palaeoenvironmental shifts drove the adaptive radiation of a noctuid stemborer tribe (Lepidoptera, Noctuidae, Apameini) in the Miocene. PLoS One 7: e41377. http://dx.doi.org/10.1371/ journal.pone. 0041377

Viette P. 1967. Insectes Lépidoptères Noctuidae Amphipyrinae (Part.) et Melicleptriinae. Faune de Madagascar. ORSTOM-CNRS, Paris 20 (2): 394-417.

White F. 1983. The vegetation of Africa, a descriptive memoir to accompany the UNESCO / AETFAT / UNSO vegetation map of Africa. UNESCO, Natural Resources Research 20: 1-356.

Zhang J., Kapli P., Pavlidis P. \& Stamatakis A. 2013. A general species delimitation method with applications to phylogenetic placements. Bioinformatics 29: 2869-2876. http://dx.doi.org/10.1093/ bioinformatics/btt499

Manuscript received: 22 December 2015

Manuscript accepted: 29 June 2016

Published on: 3 February 2017

Guest editors: Line Le Gall, Frédéric Delsuc, Stéphane Hourdez, Guillaume Lecointre and Jean-Yves Rasplus

Desk editor: Danny Eibye-Jacobsen

Printed versions of all papers are also deposited in the libraries of the institutes that are members of the EJT consortium: Muséum national d'Histoire naturelle, Paris, France; Botanic Garden Meise, Belgium; Royal Museum for Central Africa, Tervuren, Belgium; Natural History Museum, London, United Kingdom; Royal Belgian Institute of Natural Sciences, Brussels, Belgium; Natural History Museum of Denmark, Copenhagen, Denmark; Naturalis Biodiversity Center, Leiden, the Netherlands. 


\section{Appendix}

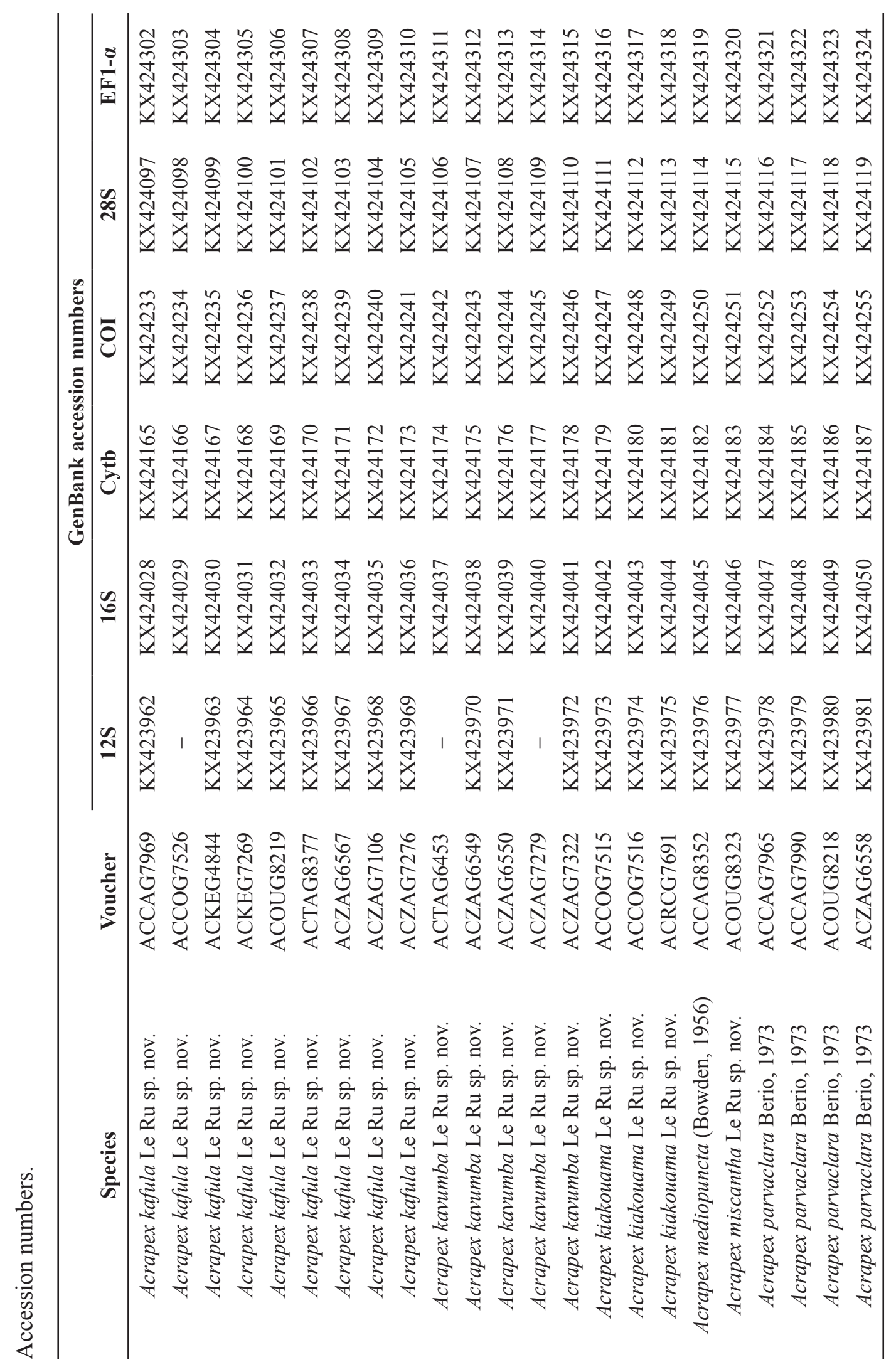




\section{Appendix (cont.)}

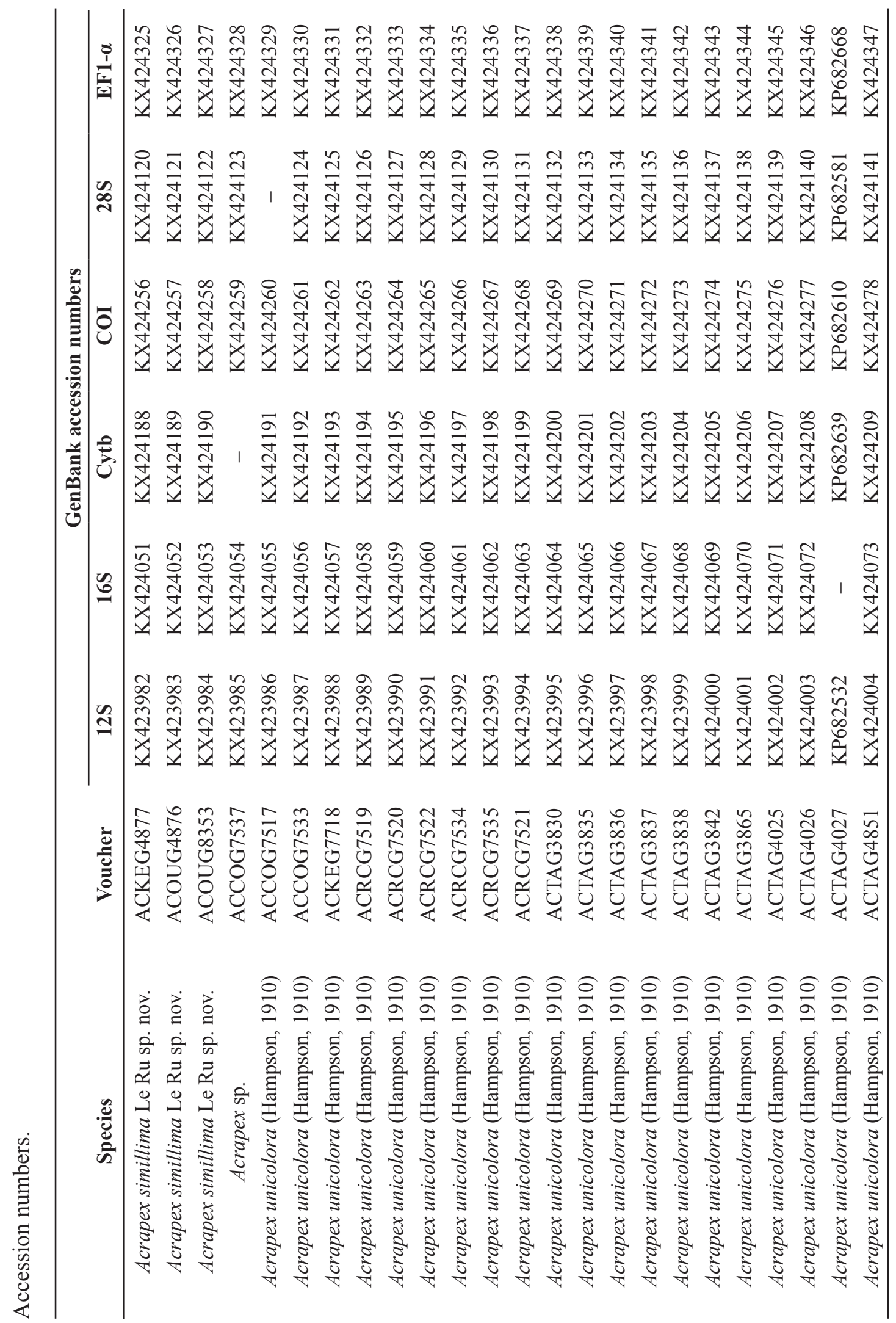




\section{Appendix (cont.)}

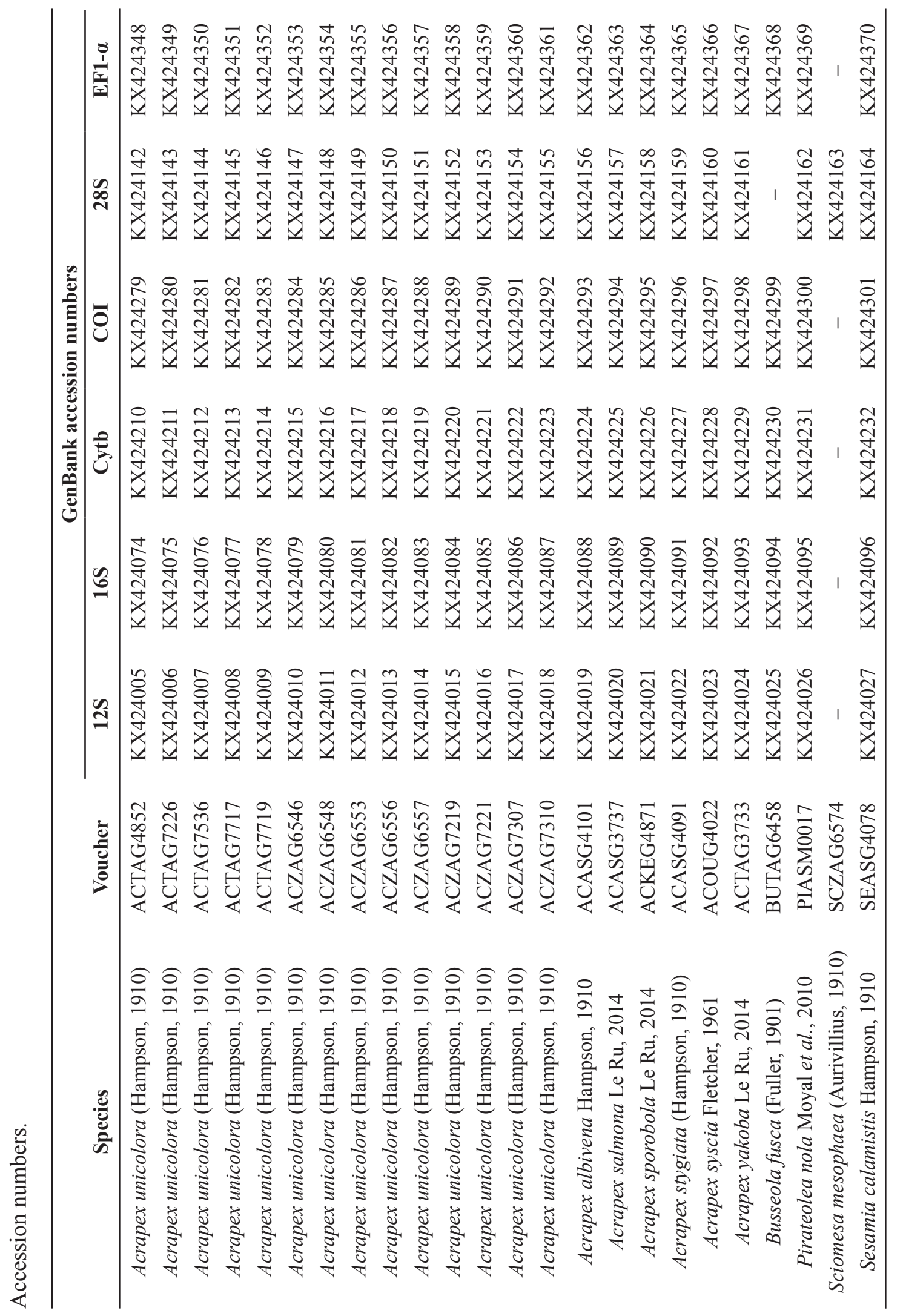

